\title{
Effect of PEG Grafting Density and Hydrodynamic Volume on Gold Nanoparticle-Cell Interactions: An Investigation on Cell Cycle, Apoptosis, and DNA Damage
}

\author{
Metin Uz, Volga Bulmus, ${ }^{\dagger}{ }^{\dagger}$ and Sacide Alsoy Altinkaya ${ }^{*}{ }^{\dagger}$ \\ ${ }^{\dagger}$ Department of Chemical Engineering, ${ }^{\ddagger}$ Department of Bioengineering, and ${ }^{\S}$ Biotechnology and Bioengineering Graduate Program, \\ Izmir Institute of Technology, Gulbahce Koyu, Urla, Izmir 35430, Turkey
}

\section{Supporting Information}

\begin{abstract}
In this study, interactions of polyethylene glycol (PEG)-coated gold nanoparticles (AuNPs) with cells were investigated with particular focus on the relationship between the PEG layer properties (conformation, grafting density, and hydrodynamic volume) and cell cycle arrest, apoptosis, and DNA damage. Steric hindrance and PEG hydrodynamic volume controlled the protein adsorption, whereas the AuNP core size and PEG hydrodynamic volume were primary factors for cell uptake and viability. At all PEG grafting densities, the particles caused significant cell cycle arrest and

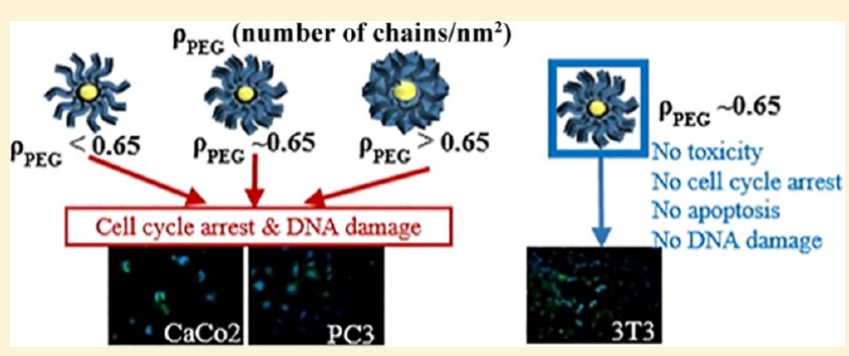
DNA damage against $\mathrm{CaCo} 2$ and PC3 cells without apoptosis. However, at a particular PEG grafting density ( $\sim 0.65$ chains/ $\mathrm{nm}^{2}$ ), none of these severe damages were observed on 3T3 cells indicating discriminating behavior of the healthy (3T3) and cancer (PC3 and $\mathrm{CaCo} 2$ ) cells. It was concluded that the PEG grafting density and hydrodynamic volume, tuned with the PEG concentration and AuNP size, played an important role in particle-cell interactions.
\end{abstract}

\section{INTRODUCTION}

Gold nanoparticles (AuNPs) are promising tools for drug/gene delivery, ${ }^{1-8}$ cellular imaging, cancer diagnostics and therapy, and theranostic applications ${ }^{9-15}$ because of their unique features such as biocompatibility, controllable sizes, easy preparation/modification, and strong plasmonic properties. $^{16-18}$ In most of the in vitro and in vivo studies, the surface of the AuNPs is modified with polyethylene glycol (PEG) to enhance colloidal stability in a physiological medium, to improve biocompatibility, ${ }^{19-23}$ and to provide conjugation sites for therapeutic agents and targeting ligands. ${ }^{4,5,8,11,24-28}$ The data in the literature demonstrate that the size, shape, and surface modification of AuNPs significantly affect their cellular uptake, ${ }^{29-37}$ intracellular localization, ${ }^{19,38-42}$ and toxicity. ${ }^{19,31,33,37,43-48}$ Although numerous studies exist focusing on the cell uptake and toxicity of AuNPs, the potential effects of surface-modified or bare AuNPs on cell cycle steps, apoptosis, and DNA damage have been investigated only in a few in vitro studies. ${ }^{19,43,49-55}$ Most of these studies correlated the interaction between the particles and cells in terms of surface charge and PEG grafting density of particles. On the other hand, the effect of the PEG hydrodynamic volume on the cellparticle interactions was rarely considered. ${ }^{56-58}$

In this work, detailed characterization of PEG-modified AuNPs is presented by investigating the effects of the core size and PEG concentration on the size, surface charge, PEG layer conformation, grafting density, and hydrodynamic volume. For this purpose, two different AuNP core sizes, 5 and $13 \mathrm{~nm}$, and three different PEG coating concentrations, $0.2,0.6$, and $1 \mathrm{mg} /$
$\mathrm{mL}$, were selected. The size of AuNPs is one of the key factors determining the mode of elimination from the body, hence dictating the in vivo biodistribution profile of the nanoparticles. To prevent the accumulation of the nonbiodegradable AuNPs in the body, the size of the nanoparticles must enable their renal clearance because this mode of elimination implies no degradation of the nanoparticle. The studies in the literature indicated that gold particles larger than $10 \mathrm{~nm}$ will inevitably be captured by the liver (or other organs of the reticuloendothelial system) after opsonization regardless of their surface properties, whereas a hydrodynamic diameter of less than $10 \mathrm{~nm}$ leads to renal elimination. ${ }^{59-62}$ Considering this fact, this study is planned based on two AuNP core sizes below and above the suggested size limit $(10 \mathrm{~nm})$. The influence of the PEG grafting density and hydrodynamic volume on the stability (protein adsorption), cell uptake, toxicity, cell cycle phases, apoptosis, and DNA damage were evaluated against prostate (PC3) and colon $(\mathrm{CaCo} 2)$ cancer cell lines and healthy $3 \mathrm{~T} 3$ fibroblast cells. These common cell types were selected because of their distinct properties and widespread use as model cancer or control cell lines in cancer nanomedicine research. ${ }^{63-66}$ To the best of our knowledge, the interaction between the PEGylated AuNPs and these cell lines has not been investigated previously.

Received: April 4, 2016

Revised: May 12, 2016

Published: May 20, 2016 


\section{MATERIALS AND METHODS}

Chemicals and Materials. Hydrogen tetrachloroaurate(III) trihydrate (99.9\%), sodium citrate, and sodium borohydrate used in the preparation of AuNPs were purchased from Sigma-Aldrich. Thiol and amine end-group-modified PEG ( $\mathrm{SH}-\mathrm{PEG}-\mathrm{NH}_{2}$ : MW 1000) used for the surface modification of nanoparticles was purchased from Creative PEG works. The fluorescence dyes, 4',6-diamidino-2phenylindole (DAPI) and fluorescein isothiocyanate (FITC), used in staining cells and PEG-coated AuNPs, respectively, were from SigmaAldrich. The colon cancer cell line, $\mathrm{CaCo} 2$ (ATCC HTB-37), prostate cancer cell line, PC-3 (ATCC CRL-1435), and 3T3 fibroblast (ATCC CRL-1658) were obtained from American Type Culture Collection. The cell culture media, Dulbecco's Modified Eagle Medium (DMEM) and RPMI Medium 1640, and cell culture medium additives, fetal bovine serum (FBS) and penicillin streptomycin, were obtained from Invitrogen. An annexin $\mathrm{V}$ staining kit for apoptosis detection, propidium iodide (PI) dye, and 3-(4,5-dimethythiazol-2-yl)-2,5diphenyl tetrazolium bromide (MTT) toxicity assay dye were obtained from Sigma-Aldrich.

Preparation of AuNPs and PEG Modification. The 5 and 13 $\mathrm{nm}$ AuNPs were prepared using classical sodium borohydrate and sodium citrate reduction, respectively. ${ }^{67,68}$ To modify the surface, the $\mathrm{SH}-\mathrm{PEG}-\mathrm{NH}_{2}$ was added to $10 \mathrm{nM}$ nanoparticle solutions. The PEG concentration in the reaction medium was $0.2,0.6$, or $1 \mathrm{mg} / \mathrm{mL}$. The reaction was carried out at room temperature in the dark under nitrogen with continuous stirring for $24 \mathrm{~h}$. At the end of the reaction, the resultant nanoparticles were centrifuged at $15000 \mathrm{rpm}$ for $20 \mathrm{~min}$ and washed with phosphate buffer (PBS) four times to eliminate weakly bound PEGs. The attached PEG amount was calculated as described in Figure S2 and Table S1 in accordance with the protocol published in the literature. ${ }^{20,69,70}$ For fluorescence microscopy imaging, the PEG-coated AuNPs were reacted with FITC dye. ${ }^{19,38}$ For this reaction, $1 \mathrm{mg}$ of FITC was dissolved in $200 \mu \mathrm{L}$ of anhydrous dimethylformamide (DMF) and added to $50 \mu \mathrm{M}$ PEG-coated AuNP solution. The suspension was vortexed and placed on a shaker for $24 \mathrm{~h}$. Free FITC molecules were removed by centrifugation and washing with PBS containing 15\% DMF. Complete removal of free FITC molecules was verified by monitoring the fluorescence of the supernatant using a fluorescence spectrophotometer.

Characterization of the Bare and PEG-Coated AuNPs. The size, size distribution, and zeta potential of the particles were determined by dynamic light scattering (DLS) (Malvern Zetasizer Nanozs90). A UV-vis spectrophotometer (Perkin Elmer Lambda45) was used to determine the change in the spectra of the particles caused by surface modification. To evaluate the stabilities of the particles, they were incubated in a serum-supplied cell culture medium at $37^{\circ} \mathrm{C}$ in a $5 \% \mathrm{CO}_{2}$-humidified atmosphere. Following incubation, the samples were centrifuged and washed with PBS to remove the medium. Then, the size and zeta potential of the particles resuspended in PBS were measured with DLS.

The naked AuNPs and AuNP-PEG particles were visualized by transmission electron microscopy (TEM) (FEI-Tecnai 2-F20). After the removal of free PEG on the surface of the particles through centrifugation and further washing with PBS, the samples were prepared by dipping a carbon-coated copper grid (Ted Pella 400 mesh $\mathrm{Cu}$ Holey Carbon) in $20 \mu \mathrm{L}$ of colloidal nanoparticle solution and air dried before taking images. For visualization of the PEG layer around AuNPs, a copper grid, prepared as described above, was immersed in a uranyl acetate $(2 \% \mathrm{v} / \mathrm{v})$ aqueous solution for $5 \mathrm{~min}$. Excess solution on the grid was wiped off using a filter paper, and residual solution was air dried. X-ray photoelectron spectroscopy (XPS) was also used to confirm the presence of the PEG layer on AuNPs. Samples were prepared by adding a small drop of an aqueous solution of AuNPs onto a silicon wafer and air dried. Analyses were performed using a monochromatic $\mathrm{Al} \mathrm{K} \alpha \mathrm{X}$-ray source $(1486.6 \mathrm{eV})$ with an Omni Focus III small-area lens and a multichannel detector. Measurements were taken at an electron take-off angle $45^{\circ}$ from a normal sampling surface depth of $\sim 50 \AA$. The binding energy scale was calibrated prior to analysis by the $\mathrm{Au} 4 \mathrm{f} 7 / 2$ peak at $83.9 \mathrm{eV}$. Survey scans were collected from 10 to $1100 \mathrm{eV}$ with a pass energy of $187.85 \mathrm{eV}$. All spectra were referenced by setting the $\mathrm{C} 1 \mathrm{~s}$ peak to $285.0 \mathrm{eV}$ to compensate for residual charging effects.

Cell Culture. PC 3 cells and 3T3 cells were cultured in high glucose DMEM supplemented with $10 \% \mathrm{FBS}$, whereas the $\mathrm{CaCo} 2$ cell line was cultured in RPMI medium supplemented with 10\% FBS. Cell cultures were kept at $37{ }^{\circ} \mathrm{C}$ in a $5 \% \mathrm{CO}_{2}$-humidified incubator and subcultured two times per week.

Cellular Uptake by Inductively Coupled Plasma Mass Spectroscopy (ICP-MS). To measure the time-dependent cellular uptake and cellular accumulation of AuNP-PEG particles, PC3, $\mathrm{CaCo} 2$, and $3 \mathrm{~T} 3$ cells $\left(2 \times 10^{5}\right.$ cell/well $)$ were plated in each well and incubated with the PEG-coated AuNPs at $37{ }^{\circ} \mathrm{C}$ in a $5 \% \mathrm{CO}_{2}$ humidified incubator for $24 \mathrm{~h}$. After incubation, the cell culture medium was removed, and the exposed cells were further washed with PBS to remove nanoparticles existing in the medium or adhering to the outer cell membrane. The cells were then harvested, dispersed into the culture medium, and collected by centrifugation. After the removal of the supernatant, the cell pellet was treated with $500 \mu \mathrm{L}$ of concentrated nitric acid $\left(\mathrm{HNO}_{3}\right)$ at $70{ }^{\circ} \mathrm{C}$ for $4 \mathrm{~h}$ to digest AuNPs. ${ }^{19}$ The quantity of Au was analyzed by ICP-MS (Agilent 7500ce) and the number of AuNPs per cell was calculated as shown in the Supporting Information.

MTT Assay. The PC3, CaCo2, and 3T3 cells $(95 \mu \mathrm{L})$ were plated at a density of $1 \times 10^{4}$ cells/well in 96-well plates. After $24 \mathrm{~h}$ incubation at $37{ }^{\circ} \mathrm{C}$ in a $5 \% \mathrm{CO}_{2}$-humidified incubator, the cells were exposed to different concentrations of 5 and $13 \mathrm{~nm}$ AuNPs $(5 \mu \mathrm{L})$ $(12.5,25$, and $50 \mu \mathrm{M})$ coated by different PEG concentrations $(0.2$, 0.6 , and $1 \mathrm{mg} / \mathrm{mL}$ ) and incubated for $24 \mathrm{~h}$. Following incubation, the cell culture medium in the well plates was removed, and $100 \mu \mathrm{L}$ of MTT dye $(0.5 \mathrm{mg} / \mathrm{mL}$ in PBS at $\mathrm{pH} 7.4)$ was added to each well and incubated for further $4 \mathrm{~h}$. At the end of incubation, the 96-well plate was centrifuged, and the medium was removed. Then, the precipitated formazan crystals were solubilized with $100 \mu \mathrm{L}$ of DMSO, and the absorbance was measured spectrophotometrically at $570 \mathrm{~nm}$ in a microplate reader (Thermo Scientific, Varioskan Multimode Microplate Reader).

Cell Cycle and Apoptosis Analysis with Flow Cytometry. $\mathrm{PC} 3, \mathrm{CaCo} 2$, and $3 \mathrm{~T} 3$ cells were grown $\left(2 \times 10^{5}\right.$ cell/well $)$ in 6-well plates at $37{ }^{\circ} \mathrm{C}$ in a $5 \% \mathrm{CO}_{2}$-humidified incubator for $24 \mathrm{~h}$ and then further incubated under the same conditions with AuNP-PEG particles $(12.5,25$, and $50 \mu \mathrm{M})$ in the culture medium for another $24 \mathrm{~h}$. After incubation, cells were harvested and centrifuged at 1200 rpm for $10 \mathrm{~min}$, and the supernatant was discarded. The precipitated cells were suspended in $1 \mathrm{~mL}$ of PBS solution, fixed with cold ethanol (at $-20{ }^{\circ} \mathrm{C}, 70 \%$ ) under continuous vortexing, and stored at $-20{ }^{\circ} \mathrm{C}$ until analysis. On the day of the experiment, the fixed cell suspensions were washed by centrifugation ( $1200 \mathrm{rpm}$ for $10 \mathrm{~min}$ ) three times, and the precipitate was suspended in $1 \mathrm{~mL}$ of PBS containing $0.1 \%$ Triton $\mathrm{X}-100$. The cells were further treated with $200 \mu \mathrm{g} / \mathrm{mL}$ RNase for 30 min at $37{ }^{\circ} \mathrm{C}$, and then, DNA staining with $100 \mu \mathrm{g} / \mathrm{mL}$ propidium iodine was conducted at room temperature for $15 \mathrm{~min}$. Samples were analyzed through a flow cytometer (BD Biosciences Facs Canto), and data were analyzed using Modfit flow cytometry analyzing software.

For the apoptosis test, the same AuNP-PEG particles at the same doses were applied to the cells and incubated as in cell cycle analysis. The cells were then harvested, washed with cold PBS, and centrifuged. The cell pellet was resuspended in annexin-binding buffer, and $5 \mu \mathrm{L}$ of annexin V FITC conjugate and PI solution were sequentially added to the sample to detect apoptotic and necrotic cell populations, respectively. Finally, the cells were incubated at room temperature for $15 \mathrm{~min}$, and measurements were conducted by using a flow cytometer.

Comet Assay. The cells grown in 6-well plates $\left(2 \times 10^{5}\right.$ cell/well $)$ were exposed to PEGylated AuNPs for $24 \mathrm{~h}$ at $37^{\circ} \mathrm{C}$ in a $5 \% \mathrm{CO}_{2^{-}}$ humidified incubator. Then, they were harvested, washed with PBS twice, and resuspended in PBS. The cell suspension $(5 \mu \mathrm{L})$ was embedded in $75 \mu \mathrm{L}$ of $1 \%$ low-melting agarose and spread on previously prepared comet slides and lysed in prechilled lysis solution [1.2 M NaCl, $100 \mathrm{mM} \mathrm{Na} 2$ EDTA, $0.1 \%$ sodium lauryl sarcosinate, and 
$0.26 \mathrm{M} \mathrm{NaOH}(\mathrm{pH}>13)]$ for $24 \mathrm{~h}$. Cells were then treated with a denaturation solution [0.03 M NaOH, 2 mM Na 2 EDTA ( $\mathrm{pH}$ 12.3)] for $45 \mathrm{~min}$ in the dark at room temperature. Following denaturation, electrophoresis was performed at $25 \mathrm{~V}$ and $90 \mathrm{~mA}$ for $20 \mathrm{~min}$. The slides were immersed in $\mathrm{dH}_{2} \mathrm{O}$ for neutralization for $15 \mathrm{~min}$. Subsequently, they were stained with PI dye $(10 \mu \mathrm{g} / \mathrm{mL})$ for 20 min and washed with water to remove excess dye. ${ }^{71}$ Hydrogen peroxide $\left(\mathrm{H}_{2} \mathrm{O}_{2}\right)$ was used as the positive control. The images were taken by using fluorescence microscopy and analyzed using image analysis software.

Fluorescence Microscopy. PC3, CaCo2, and 3T3 cells $\left(2 \times 10^{5}\right.$ cell/well) were plated in each well and grown on a microscope slide at $37{ }^{\circ} \mathrm{C}$ in a $5 \% \mathrm{CO}_{2}$-humidified incubator for $24 \mathrm{~h}$. The cells were further incubated with the FITC-attached PEG-coated AuNPs for $24 \mathrm{~h}$ under the same conditions. After incubation, the cell culture medium was removed, and the exposed cells were further washed with PBS. The cells were then fixed with $4 \%$ paraformaldehyde (PFA) in PBS for $20 \mathrm{~min}$ at room temperature, washed with PBS three times, and permeabilized with $1 \mathrm{~mL}$ of $0.1 \%$ Triton X-100 in PBS for 15 min at room temperature. Following this, the cells were blocked with $0.5 \mathrm{~mL}$ of $3 \%$ BSA in $0.1 \%$ Triton X-100/PBS for $30 \mathrm{~min}$. Finally, the cells were incubated with $100 \mu \mathrm{L}$ of DAPI dye for $5 \mathrm{~min}$ in the dark. At the end of incubation, the cells were washed with PBS and mounted with 1:1 PBS/glycerol on a microscope slide before taking fluorescence images.

Statistical Analysis. The significant difference between the groups was evaluated by ANOVA analysis by Tukey's method with a $95 \%$ confidence interval. The results were presented as mean, and standard deviations were calculated from at least three independent experiments with three repeats.

\section{RESULTS AND DISCUSSION}

Characterization of PEG-Modified AuNPs. Two different sized $(\sim 5$ and $\sim 13 \mathrm{~nm})$ bare AuNPs were synthesized and modified with varying amounts of heterobifunctional PEG (SH-PEG- $\mathrm{NH}_{2}: 0.2,0.6$, and $1 \mathrm{mg} / \mathrm{mL}$ ) to prepare PEGcoated AuNPs with different sizes and surface properties. The code of the nanoparticles along with the preparation conditions are shown in Scheme 1.

\section{Scheme 1. Description of PEG-Coated AuNPs}

\begin{tabular}{|c|c|c|c|}
\hline $\mathrm{C}_{\mathrm{PEG}}$ & $0.2 \mathrm{mg} / \mathrm{mL}$ & $0.6 \mathrm{mg} / \mathrm{mL}$ & $1 \mathrm{mg} / \mathrm{mL}$ \\
\hline $5 \mathrm{~nm}$ AuNP & Particle A & \\
\hline $13 \mathrm{~nm}$ AuNP & &
\end{tabular}

The PEG layer coated on the AuNPs is observed in TEM images shown in Figure 1 and its thickness is calculated from DLS data (size distributions of particles are shown in Figure S3). The TEM images clearly revealed the presence of the PEG layer around AuNPs. The results in Table 1 have shown that when the PEG concentration in the feed is increased, the thickness of the PEG layer on both 5 and $13 \mathrm{~nm}$ sized nanoparticles increases significantly $(p<0.05)$ (from 7.59 to $9.85 \mathrm{~nm}$ for $5 \mathrm{~nm}$ AuNPs and from 5.16 to $7.04 \mathrm{~nm}$ for $13 \mathrm{~nm}$ AuNPs). ${ }^{23,69}$
The change in zeta potential values was another indication of successful PEG coating. Upon PEG attachment, the negatively charged surfaces of the bare AuNPs became positively charged because of the presence of $-\mathrm{NH}_{2}$ groups at the open end of the PEG (Table 1). The PEG concentration caused a slight increase in the zeta potential of the conjugates formed from 5 $\mathrm{nm}$ AuNPs, whereas the zeta potential of the $13 \mathrm{~nm}$ sized nanoparticles increased significantly by increasing the PEG concentration from 0.2 to $1 \mathrm{mg} / \mathrm{mL}$. The XPS data and the $\mathrm{UV}$-vis spectra of the nanoparticles also confirmed the success of surface modification (Figures S4-S7). The stabilities of the particles in the serum-supplemented cell culture medium were evaluated through the changes in the size and zeta potential values (Table 1). The bare AuNPs showed a significant agglomeration tendency. Their sizes increased, whereas their zeta potential values decreased because of the attachment of cell culture medium components. In general, the PEG-coated AuNPs, except particles B and C (Table 1), were stable in the medium as confirmed by no significant change in their sizes after incubation with the medium.

The conformation of PEG chains attached to the nanoparticles was calculated from the Flory radius $\left(R_{\mathrm{F}}\right)$. As shown in eq 1 , the Flory radius is a function of the PEG size $(a=3.5 \AA)$ and the number of monomer units $(N) .{ }^{69,72}$

$$
R_{\mathrm{F}}=a N^{3 / 5}
$$

The PEG chains can acquire either 'mushroom' or 'brush' configurations. The mushroom conformation mainly occurs when the distance, $D$, between the attachment points of PEG to the surface is larger than $R_{\mathrm{F}}\left(D>R_{\mathrm{F}}\right)$; however, the brush conformation is observed when $D<R_{\mathrm{F}}$. 49,69

Using the thickness of the PEG layer obtained from DLS measurements $(t)$ and the density of PEG $(\rho=1.09 \mathrm{~g} / \mathrm{mL})$, the surface concentration $\left(\Gamma, \mathrm{g} / \mathrm{nm}^{2}\right)$ and the average distance between grafted PEG chains $(D, \mathrm{~nm})$ were calculated using eqs 2 and 3 , respectively.

$$
\begin{aligned}
& \Gamma=\rho t \\
& D=\left(\frac{M}{\Gamma N_{\mathrm{A}}}\right)^{1 / 2} \\
& \sigma=\left(\frac{a}{D}\right)^{2}
\end{aligned}
$$

In eqs 3 and $4, M$ is the PEG molecular weight $(\mathrm{Da}), N_{\mathrm{A}}$ is Avogadro's number $\left(6.02 \times 10^{23} \mathrm{~mol}^{-1}\right)$, and $\sigma$ is the grafting density. The hydrodynamic volume of the single PEG molecule attached on the AuNP surface was calculated by dividing the total hydrodynamic volume of the PEG layer formed on AuNPs by the total number of PEG molecules per nanoparticle. The conformation, PEG grafting densities, and PEG hydrodynamic volumes of the particles determined from the above given calculations are summarized in Table 1 .

Theoretical calculations indicated that the PEG layers deposited on each particle possessed brush-like conformation (Table 1). This finding suggested that a sufficient amount of PEG was indeed utilized for the modification of particles leading to the PEG chains to adopt a brush-like conformation rather than a mushroom-like conformation. ${ }^{23,69,72,73}$ The PEG grafting density on the particles increased with the increased PEG concentration (Table 1). PEGylation on $5 \mathrm{~nm}$ sized AuNPs yielded a higher grafting density than that on the $13 \mathrm{~nm}$ 


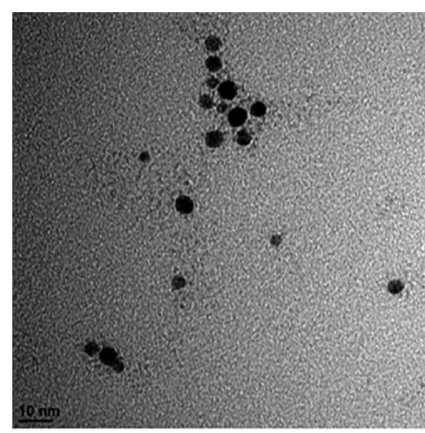

$5 \mathrm{~nm}$ Bare AuNP

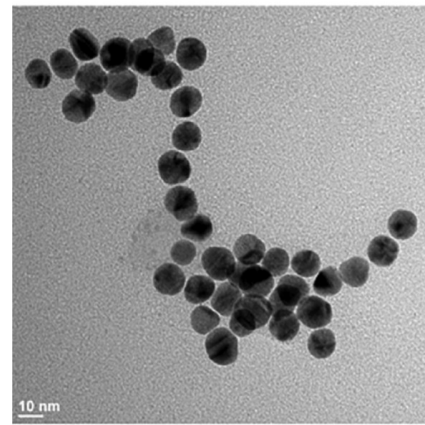

$13 \mathrm{~nm}$ Bare AuNP

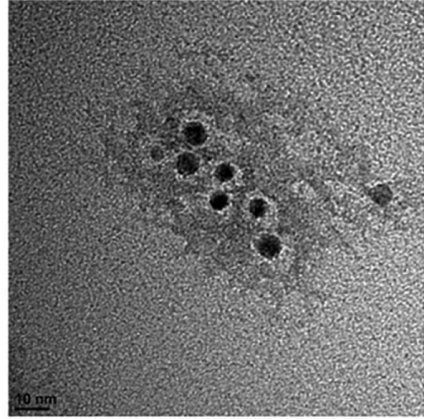

Particle A

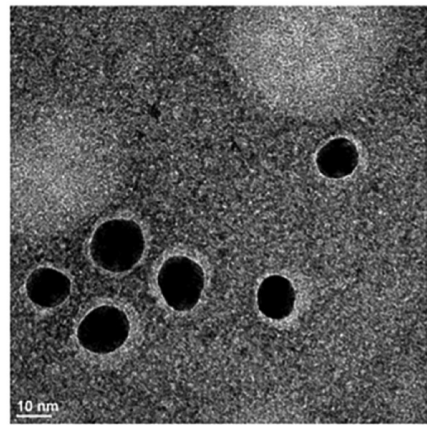

Particle D

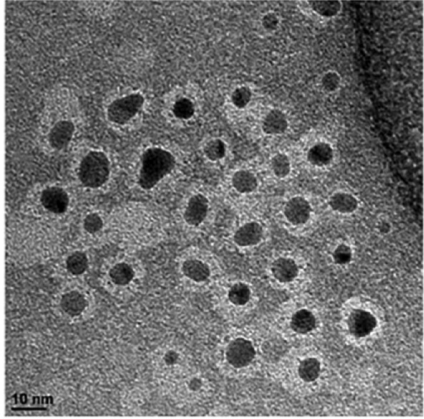

Particle B

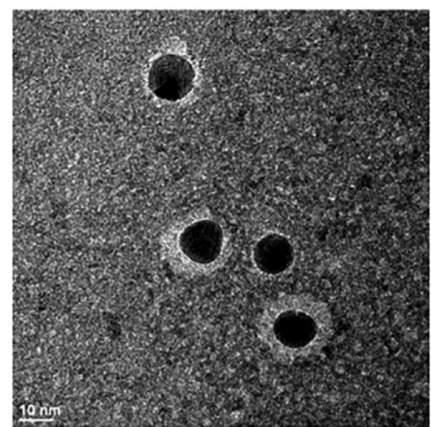

Particle E

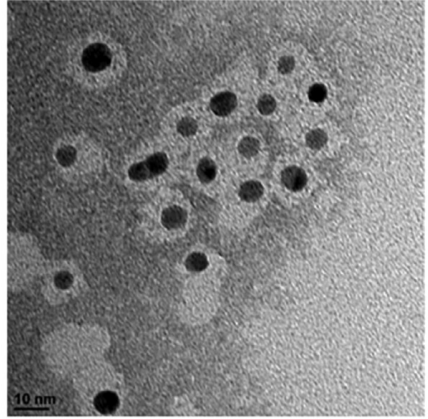

Particle C

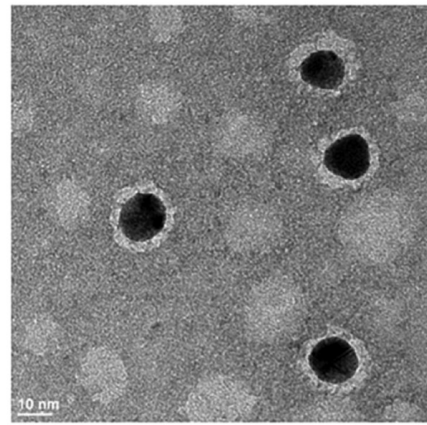

Particle F

Figure 1. TEM images of bare and PEG-coated AuNPs. AuNP size: 5 and $13 \mathrm{~nm}$. Applied PEG concentration: 0.2, 0.6, and $1 \mathrm{mg} / \mathrm{mL}$.

Table 1. Intensity-Averaged Sizes and Zeta Potential Values of Prepared Particles before and after Serum-Supplemented Cell Culture Medium Incubation, Conformation, PEG Layer Thickness, Grafting Density, and Hydrodynamic Volume of AuNPPEG Particles ${ }^{a}$

\begin{tabular}{|c|c|c|c|c|c|c|c|c|}
\hline & \multicolumn{4}{|c|}{ before serum incubation } & \multicolumn{4}{|c|}{ after serum incubation } \\
\hline & $\begin{array}{l}5 \mathrm{~nm} \text { bare } \\
\text { AuNP }\end{array}$ & particle A & particle B & particle C & $\begin{array}{l}5 \mathrm{~nm} \text { bare } \\
\text { AuNP }\end{array}$ & particle A & particle B & particle C \\
\hline size $(\mathrm{nm})$ & $5.5 \pm 1.2$ & $13.09 \pm 0.35$ & $14.87 \pm 0.62^{\mathrm{a}}$ & $15.35 \pm 1.34^{\mathrm{a}}$ & $140.3 \pm 5.97$ & $13.5 \pm 0.24$ & $21.04 \pm 0.36^{\mathrm{c}}$ & $20.9 \pm 1.34^{\mathrm{c}}$ \\
\hline zeta potential $(\mathrm{mV})$ & $-34.4 \pm 0.9$ & $11.2 \pm 0.28$ & $15.6 \pm 1.03$ & $12.6 \pm 1.03$ & $-12.6 \pm 0.06$ & $-7.7 \pm 0.24$ & $-20.8 \pm 1.63^{\mathrm{d}}$ & $-21.5 \pm 1.15^{\mathrm{d}}$ \\
\hline PEG layer thickness (nm) & & $7.59 \pm 0.24$ & $9.37 \pm 0.62$ & $9.85 \pm 1.34$ & & & & \\
\hline $\begin{array}{l}\text { grafting density } \\
\left(\text { no. of chains } / \mathrm{nm}^{2}\right)\end{array}$ & & $0.67 \pm 0.02$ & $0.75 \pm 0.05$ & $0.92 \pm 0.1$ & & & & \\
\hline $\begin{array}{l}\text { PEG hydrodynamic } \\
\text { volume } V_{\mathrm{PEG}}\left(\mathrm{nm}^{3}\right)\end{array}$ & & $17.79 \pm 0.52$ & $16.72 \pm 1.09$ & $15.48 \pm 1.36$ & & & & \\
\hline \multirow[t]{3}{*}{ conformation } & & & brush $\left(R_{\mathrm{F}}>D\right)$ & & & & & \\
\hline & \multicolumn{4}{|c|}{ before serum incubation } & \multicolumn{4}{|c|}{ after serum incubation } \\
\hline & $\begin{array}{l}13 \mathrm{~nm} \text { bare } \\
\text { AuNP }\end{array}$ & particle D & particle E & particle $\mathrm{F}$ & $\begin{array}{l}13 \text { nm bare } \\
\text { AuNP }\end{array}$ & particle D & particle E & particle $\mathrm{F}$ \\
\hline size $(\mathrm{nm})$ & $11.78 \pm 1.34$ & $16.94 \pm 0.26$ & $18.37 \pm 0.99^{b}$ & $18.83 \pm 0.07^{\mathrm{b}}$ & $340 \pm 17.7$ & $16.39 \pm 0.59$ & $18.93 \pm 0.58^{\mathrm{e}}$ & $19.5 \pm 1.5^{\mathrm{e}}$ \\
\hline zeta potential $(\mathrm{mV})$ & $-32.5 \pm 1.67$ & $16.1 \pm 0.67$ & $19.6 \pm 0.32$ & $21.6 \pm 0.23$ & $-26.5 \pm 0.64$ & $-10 \pm 0.19$ & $-21.2 \pm 1.66^{\mathrm{f}}$ & $-21.1 \pm 1.3^{\mathrm{f}}$ \\
\hline PEG layer thickness (nm) & & $5.16 \pm 0.26$ & $6.59 \pm 0.85$ & $7.04 \pm 0.07$ & & & & \\
\hline $\begin{array}{l}\text { grafting density } \\
\left(\text { no. of chains } / \mathrm{nm}^{2}\right)\end{array}$ & & $0.36 \pm 0.05$ & $0.53 \pm 0.08$ & $0.62 \pm 0.12$ & & & & \\
\hline $\begin{array}{l}\text { PEG hydrodynamic } \\
\text { volume } V_{\mathrm{PEG}}\left(\mathrm{nm}^{3}\right)\end{array}$ & & $11.05 \pm 1.12$ & $10.47 \pm 1.58$ & $9.11 \pm 0.58$ & & & & \\
\hline conformation & & & $\operatorname{brush}\left(R_{\mathrm{F}}>D\right)$ & & & & & \\
\hline
\end{tabular}

sized ones because of the higher surface area and curvature of small nanoparticles (size of $5 \mathrm{~nm}$ ) allowing more PEG attachment than the big ones (size of $13 \mathrm{~nm}$ ), which is in agreement with the findings in the literature. ${ }^{23,69}$ Experimental quantification also indicated a higher PEG amount conjugated onto $5 \mathrm{~nm}$ sized AuNPs (Figure S2 and Table S1). For the particles prepared from the same core, as the PEG grafting density increased, the hydrodynamic volume decreased because of the compression of neighboring PEG molecules. On the other hand, both the PEG grafting density and PEG hydrodynamic volume decreased with the increased core size ( 5 vs $13 \mathrm{~nm}$ ). PEG chains on $5 \mathrm{~nm}$ particles adopt larger hydrodynamic volumes compared with those on $13 \mathrm{~nm}$ particles. This was attributed to the higher surface curvature of smaller nanoparticles, reducing steric hindrance between neighboring PEG molecules. ${ }^{23}$ Moreover, our results showed that under equal PEG density, the PEG hydrodynamic volume controlled the surface charge (Table 1). Particles A and B and 

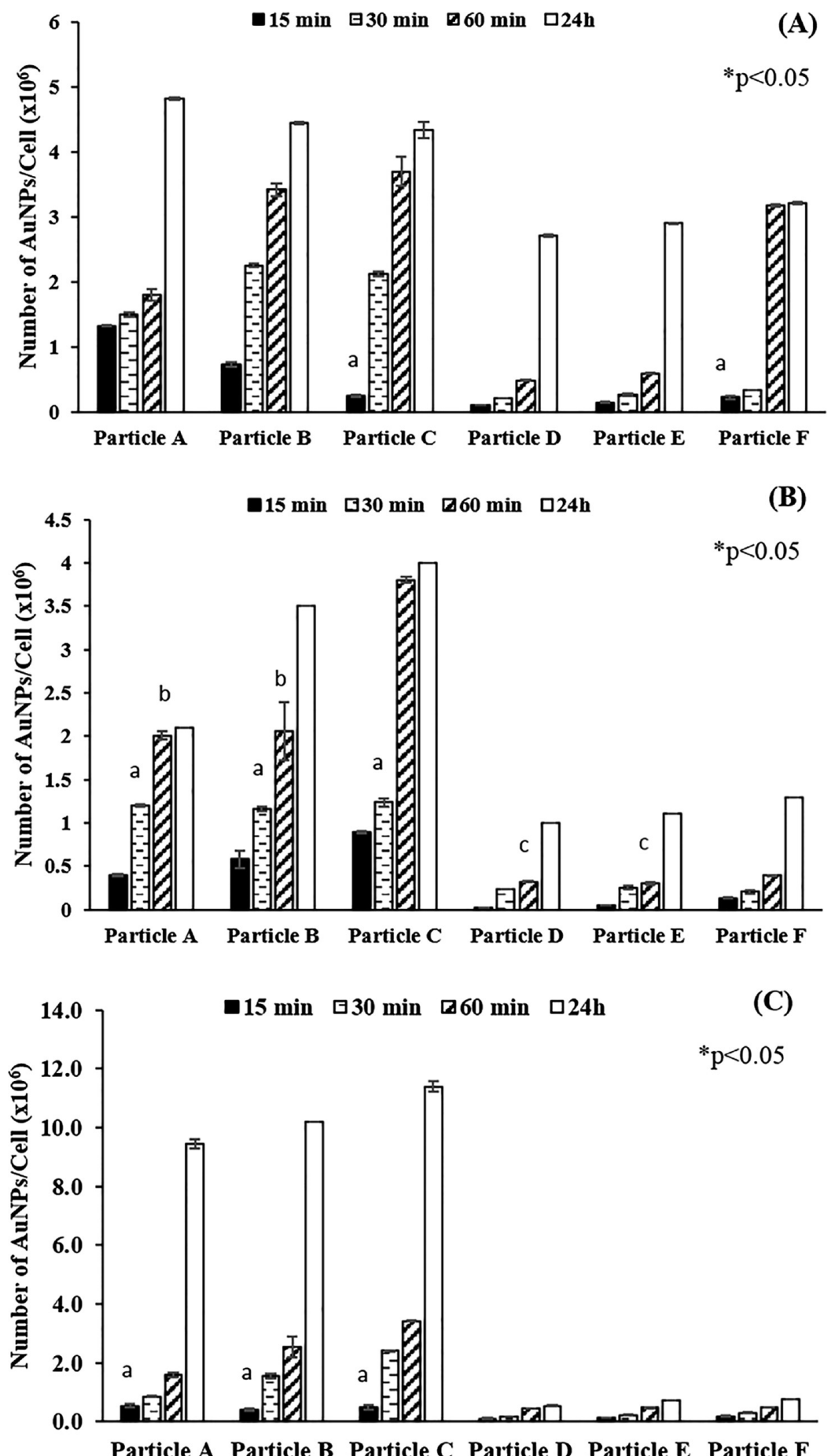

Figure 2. Time-dependent cellular uptake of PEG-modified AuNPs in (A) CaCo2 cells, (B) PC3 Cells (C) 3T3 Cells. Applied dose: $50 \mu$ M. Incubation times: 15,30 , and $60 \mathrm{~min}$ and $24 \mathrm{~h}$. The values reported at the end of $24 \mathrm{~h}$ incubation represent the cellular accumulation of the particles. The cellular accumulation of $5 \mathrm{~nm}$ bare AuNPs at the end of $24 \mathrm{~h}$ incubation was $0.16 \times 10^{6} \pm 0.03$ for CaCo2, $0.86 \times 10^{6} \pm 0.04$ for PC3, and 0.21 $\times 10^{6} \pm 0.00$ for $3 \mathrm{~T} 3$ cells. The cellular accumulation of $13 \mathrm{~nm}$ bare AuNPs at the end of $24 \mathrm{~h}$ incubation was $0.02 \times 10^{6} \pm 0.00 \mathrm{for}$ CaCo2, $0.05 \times$ $10^{6} \pm 0.00$ for PC3, and $0.02 \times 10^{6} \pm 0.00$ for 3 T3 cells. The same letters indicate the statistical indifference: a $-c(p>0.05)$. * indicates the statistical difference for all cases: $* p<0.05$.

particles E and F have similar PEG grafting densities; however, the zeta potential of particles $\mathrm{A}$ and $\mathrm{B}$ was found to be lower. The hydrodynamic volume occupied by PEG molecules is larger on particles A and B. As a result, the positively charged $-\mathrm{NH}_{2}$ end groups on the PEG chains are partly embedded in the voids of the PEG layer on the surface, decreasing the zeta potential value. It should also be noted that an increased PEG grafting density leads to higher zeta potential values because of the presence of more positively charged amine groups on the surface of the particles.

We qualitatively evaluated the serum protein adsorption levels from the changes in the zeta potential values upon incubating the nanoparticles with the serum containing cell culture media. For the particles with similar sizes prepared from 
$\square 50 \mu \mathrm{M} \quad \square 25 \mu \mathrm{M} \quad \square 12.5 \mu \mathrm{M}$

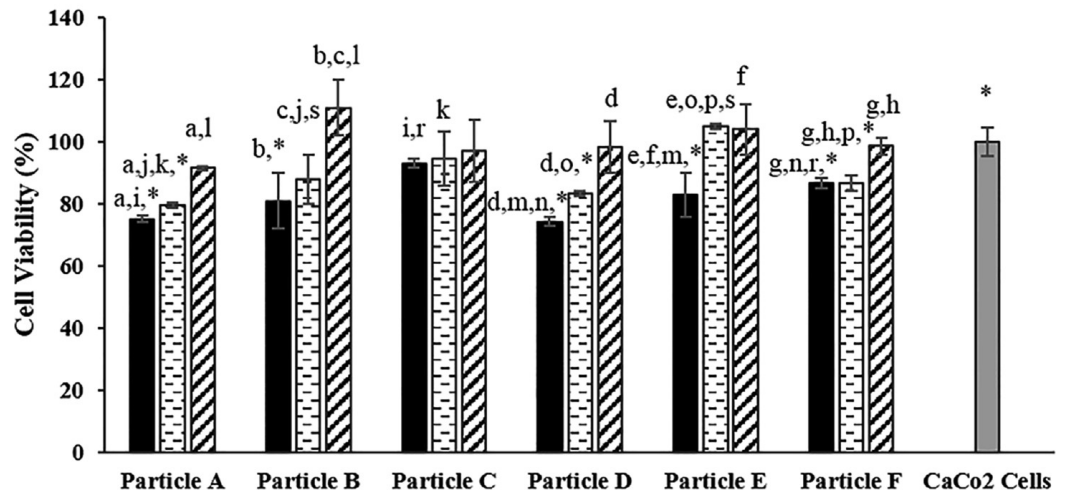

Figure 3. Cell viability of $\mathrm{CaCo} 2$ cells exposed to AuNP-PEG particles. Incubation time: $24 \mathrm{~h}$. a-h represent doses of particles which caused significant difference in cell viability. i represents PEG coating concentration that caused a significant difference in cell viability for particles A and C at a dose of $50 \mu \mathrm{M}$. j and k represent PEG coating concentration that caused a significant difference in cell viability for particle A and particles B and $\mathrm{C}$ at a dose of $25 \mu \mathrm{M}$. 1 represents PEG coating concentration that caused a significant difference in cell viability for particles A and B at a dose of $12.5 \mu \mathrm{M}$. $\mathrm{m}$ and $\mathrm{n}$ represent PEG coating concentration that caused a significant difference in cell viability for particle $\mathrm{D}$ and particles $\mathrm{E}$ and $\mathrm{F}$ at a dose of $50 \mu \mathrm{M}$, respectively. $\mathrm{o}$ and $\mathrm{p}$ represent PEG coating concentration that caused a significant difference in cell viability for particles D and $\mathrm{E}$ and particles $\mathrm{E}$ and $\mathrm{F}$ at a dose of $25 \mu \mathrm{M}$. $\mathrm{r}$ and s represent the significant difference in the effect of the bare AuNP size on cell viability for particles $\mathrm{C}$ and $\mathrm{F}$ at a dose of $50 \mu \mathrm{M}$ and particles $\mathrm{B}$ and $\mathrm{E}$ at a dose of $25 \mu \mathrm{M}$, respectively. * represents the statistically significant effect of particles with respect to control cells $(p<0.05)$.

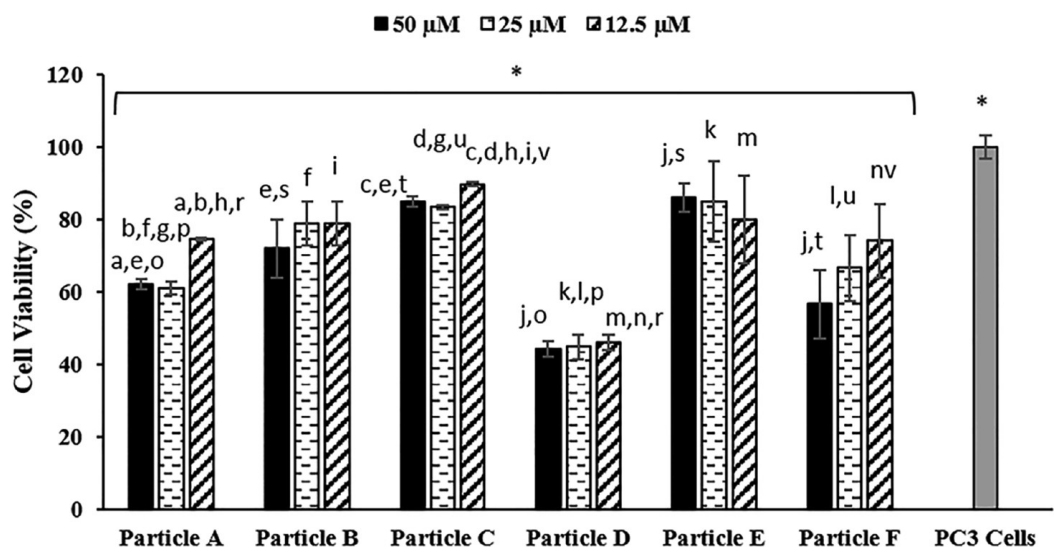

Figure 4. Cell viability of PC 3 cells exposed to AuNP-PEG particles. Incubation time: $24 \mathrm{~h}$. a $-\mathrm{d}$ represent doses of particles that caused a significant difference in cell viability. e represents PEG coating concentration that caused a significant difference in cell viability for particles A-C at $50 \mu \mathrm{M}$ dose. $\mathrm{f}$ and $\mathrm{g}$ represent the significant difference in the effect of PEG concentration on cell viability for particle $\mathrm{A}$ and particles $\mathrm{B}$ and $\mathrm{C}$ at $25 \mu \mathrm{M}$ dose. $\mathrm{h}$ and $\mathrm{i}$ represent PEG coating concentration that caused a significant difference in cell viability for particles $\mathrm{A}$ and $\mathrm{C}$ and particles $\mathrm{B}$ and $\mathrm{C}$ at $12.5 \mu \mathrm{M}$ dose, respectively. j represents PEG coating concentration that caused significant difference in cell viability for particles D-F at $50 \mu \mathrm{M}$ dose. $\mathrm{k}$ and 1 represent the significant difference in the effect of PEG concentration on cell viability for particle D and particles E and F at $25 \mu \mathrm{M}$ dose. $\mathrm{m}$ and $\mathrm{n}$ represent the significant difference in the effect of PEG concentration on cell viability for particle $\mathrm{D}$ and particles $\mathrm{E}$ and $\mathrm{F}$ at $12.5 \mu \mathrm{M}$ dose. $\mathrm{o}$, $\mathrm{p}$, and $\mathrm{r}$ represent the effect of the bare AuNP size that caused a significant difference in cell viability for particles $\mathrm{A}$ and $\mathrm{D}$ at all doses. $\mathrm{s}$ and $\mathrm{t}$ represent the significant difference in the effect of the bare AuNP size on cell viability for particles $\mathrm{B}$ and $\mathrm{E}$ and particles $\mathrm{C}$ and $\mathrm{F}$ at $50 \mu \mathrm{M}$ dose. $\mathrm{u}$ and $\mathrm{v}$ represent the significant difference in the effect of the bare AuNP size on cell viability for particles $\mathrm{C}$ and $\mathrm{F}$ at 25 and $12.5 \mu \mathrm{M}$ doses, respectively. * represents the statistically significant effect of particles with respect to control cells $(p<0.05)$.

the same core (particles $\mathrm{A}-\mathrm{C}$ or particles $\mathrm{D}-\mathrm{F}$ ), the protein adsorption level increased with the increased zeta potential (Table 1). It is expected that the zeta potential value increases with the increased grafting density of amine-terminated PEG molecules leading to higher protein adsorption. In the case of particles with similar sizes prepared from different cores (particles C vs particle D), the protein adsorption level decreased with the decrease in the PEG hydrodynamic volume. Although particle $\mathrm{D}$ has a higher zeta potential value than particle C, lower protein adsorption on particle D suggested that the hydrodynamic volume plays a more dominant role in the protein adsorption rather than the PEG grafting density, hence resulting in the difference in the zeta potential. The dominance of the hydrodynamic volume disappears when the zeta potential of the particles are significantly different. The protein adsorption resulted in an increase in the sizes of particles B and C as compared with that of particle A (Table 1). This might be because of the presence of the higher density of positively charged $-\mathrm{NH}_{2}$ groups on the surfaces of particles $\mathrm{B}$ and $\mathrm{C}$, enhancing the possibility of negatively charged cell culture media components, such as albumin with an average hydrodynamic diameter of $\sim 7 \mathrm{~nm},,^{74-76}$ to be attached to the surface. On the other hand, the lower grafting density and higher hydrodynamic volume of PEG on particle A possibly allows proteins to penetrate and embed into the PEG layer 


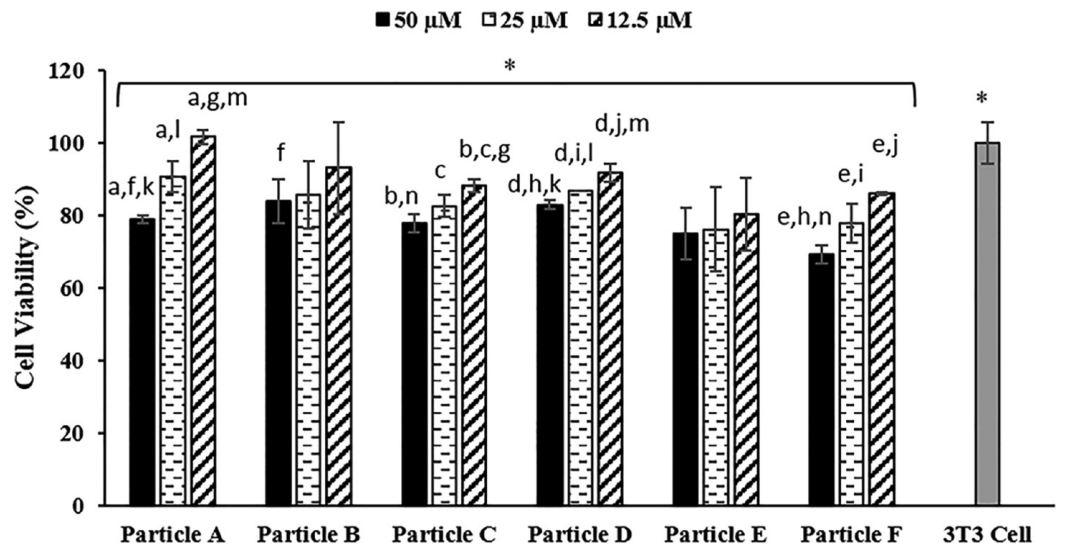

Figure 5. Cell viability of 3T3 cells exposed to AuNP-PEG particles. Incubation time: $24 \mathrm{~h}$. a-e represent doses of particles that caused a significant difference in cell viability. $f$ and $g$ represent PEG coating concentration that caused a significant difference in cell viability for particles A and B at a dose of $50 \mu \mathrm{M}$ and particles $\mathrm{A}$ and $\mathrm{C}$ at a dose of $12.5 \mu \mathrm{M}$, respectively. $\mathrm{h}-\mathrm{j}$ represent the significant difference in the effect of PEG concentration on cell viability for particles $\mathrm{D}-\mathrm{F}$ at all doses. $\mathrm{k}-\mathrm{m}$ represent the effect of the bare AuNP size that caused a significant difference in cell viability for all doses of particles A and D. $\mathrm{n}$ represents the significant difference in the effect of the bare AuNP size on cell viability for particles $\mathrm{C}$ and $\mathrm{F}$ at a dose of $50 \mu \mathrm{M}$. * represents the statistically significant effect of particles with respect to control cells except particle A at a dose of $12.5 \mu \mathrm{M}(p<0.05)$.

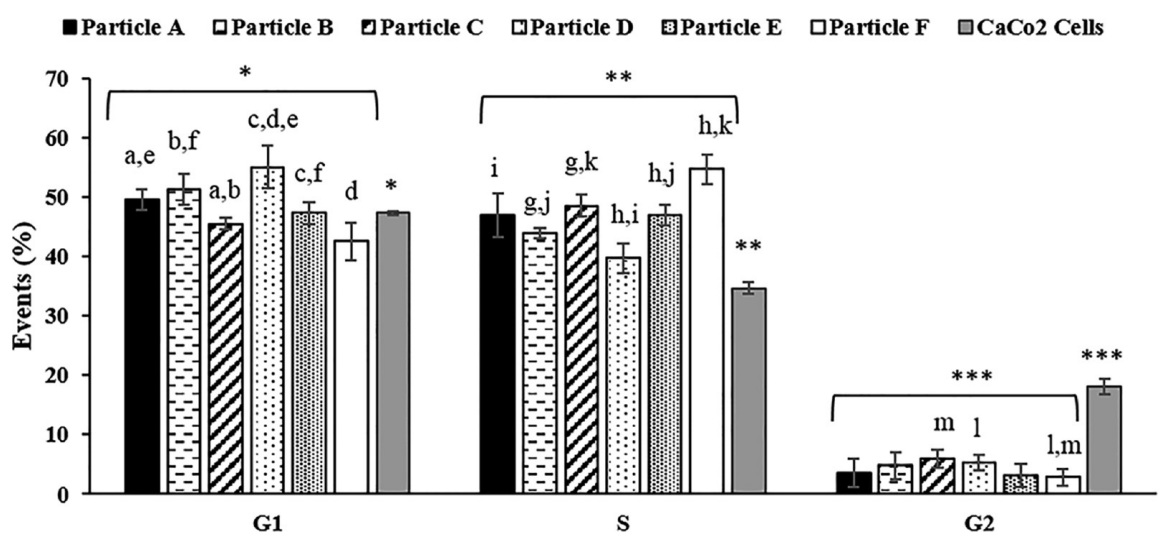

Figure 6. Complete cell cycle analysis of AuNP-PEG particle-exposed $(50 \mu \mathrm{M}) \mathrm{CaCo} 2$ cells. Incubation time: 24 h. a-d represent the significant difference in the G1 phase of cell cycle caused by the effect of PEG concentration and e and $f$ represent the significant effect of the AuNP core size on the G1 phase. $g$ and $h$ represent the significant difference caused by PEG concentration in the $S$ phase of cell cycle, whereas i-k represent the effect of the AuNP core size significantly altering the $S$ phase. 1 represents the significant difference in the G2 phase of cell cycle caused by the effect of PEG concentration, whereas m represents the significant difference in the G2 phase of cell cycle caused by the AuNP core size. *, **, and *** represent the significant difference of AuNP-PEG particles with respect to control groups for G1, S, and G2 phases, respectively, ( $p<0.05)$.

causing an insignificant size increase. The same applies to particles D-F, which have lower PEG grafting densities.

Cellular Uptake and Cytotoxicity of PEG-Modified AuNPs. Time-dependent uptake and accumulation of particles by $\mathrm{CaCo} 2, \mathrm{PC} 3$, and 3T3 cells is investigated by measuring the $\mathrm{Au}$ amount internalized by cells using ICP-MS. After $24 \mathrm{~h}$ incubation of particles with cells, the amount of bare AuNPs in all cell types was considerably lower than that of PEG-modified particles because of a huge size increase of bare AuNPs resulted from excessive agglomeration in serum containing cell culture media (Figure 2). This indicates the advantage of PEGylation on colloidal stability of AuNPs in serum containing media enhancing their cellular uptake and accumulation. It was also observed that the accumulation of the same particles significantly varies depending on the cell line because of different cellular characteristics. ${ }^{55,63}$ Figure 2 illustrates that the uptake and cellular accumulation of particle C (and particle B) are higher than those of particle F. Although their sizes and zeta potential values after serum incubation are the same (Table 1), this result suggests that the core size, PEG grafting density, and/or hydrodynamic volume may control the cellular uptake.
In the case of particles $\mathrm{A}$ and $\mathrm{F}$ having the same grafting densities, the higher uptake and accumulation of particle $A$ than those of particle $\mathrm{F}$ led to the conclusion that the dominant factor on the uptake is either the PEG hydrodynamic volume or the core size rather than the PEG grafting density of the particles. This conclusion has indeed been confirmed by the observation that particles $\mathrm{D}-\mathrm{F}$ or particles $\mathrm{A}-\mathrm{C}$ were taken up by the cells at nearly the same rates although they have a different surface charge, size, and grafting density but similar PEG hydrodynamic volumes and the same core size.

The toxicities of the nanoparticles were found to be dose dependent as illustrated in Figures 3-5. The increase in the applied dose resulted in a decrease in the viability of all cell lines with $\mathrm{LD}_{50}>50 \mu \mathrm{g} / \mathrm{mL}$. In general, the particles did not show severe toxic effects on $\mathrm{CaCo} 2$ and $3 \mathrm{~T} 3$ cell lines, especially at low doses $(12.5$ and $25 \mu \mathrm{M})$, whereas their toxic impact on PC3 cells were more severe (Figure 4) even in the lowest applied dose for particle D. Although the accumulation of particles $\mathrm{A}$ and $\mathrm{C}$ was at least 10 -fold higher than that of particles $\mathrm{D}$ and $\mathrm{F}$, their effects on the cell viability were similar or less. This result is in accordance with cellular uptake results. 


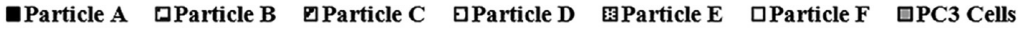

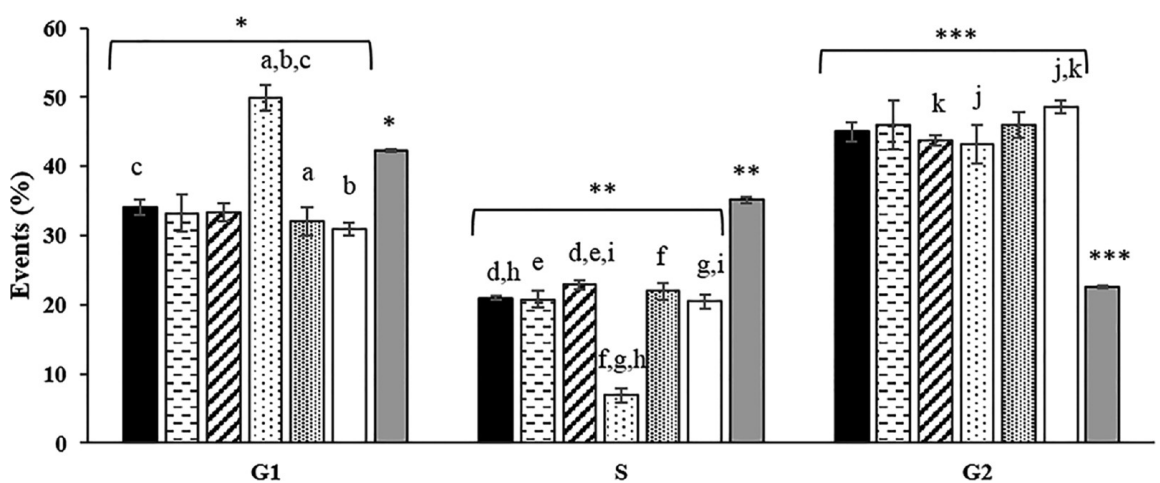

Figure 7. Complete cell cycle analysis of AuNP-PEG particle-exposed (50 $\mu \mathrm{M})$ PC 3 cells. Incubation time: $24 \mathrm{~h}$. a and b represent the significant difference in the G1 phase of cell cycle caused by the effect of PEG concentration, and c represents the significant effect of size. $d-g$ represent the significant difference caused by PEG concentration in the $S$ phase of cell cycle, whereas $h$ and $i$ represent the effect of the AuNP core size significantly altering the $S$ phase. $j$ represents the significant difference in the $G 2$ phase of cell cycle caused by the effect of PEG concentration, whereas $\mathrm{k}$ represents the significant difference due to the effect of AuNP core size. *,**, and *** represent the significant difference of AuNP-PEG particles with respect to control groups for G1, S, and G2 phases, respectively, $(p<0.05)$.

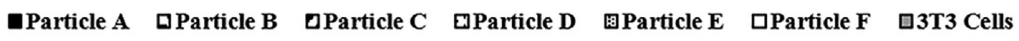

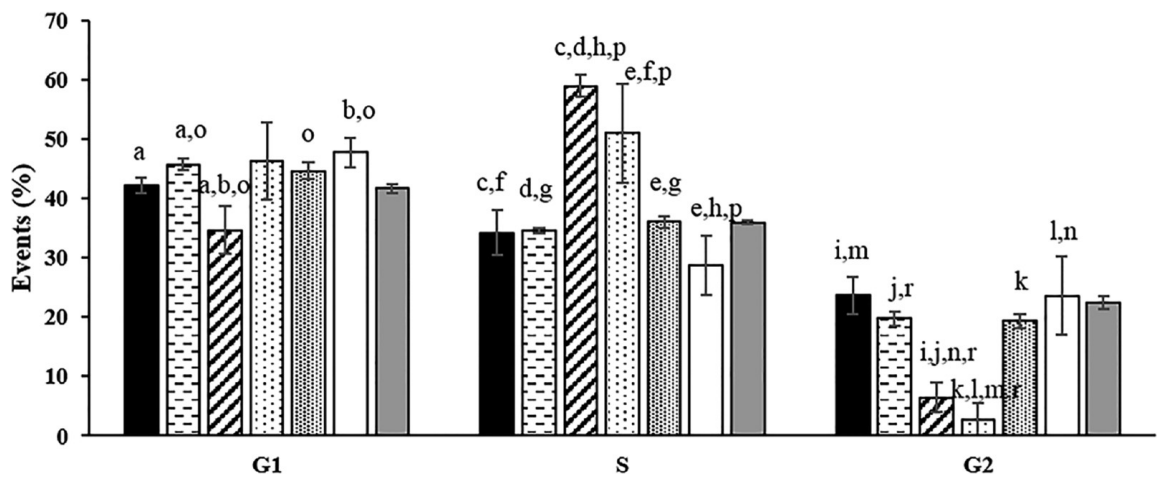

Figure 8. Complete cell cycle analysis of AuNP-PEG particle-exposed $(50 \mu \mathrm{M}) 3 \mathrm{~T} 3$ cells. Incubation time: $24 \mathrm{~h}$. a represents the significant difference in the G1 phase of cell cycle caused by the effect of PEG concentration, and b represents the significant effect of the AuNP core size. c-e represent the significant difference caused by PEG concentration in the S phase of cell cycle, whereas $\mathrm{f}-\mathrm{h}$ represent the effect of the AuNP core size significantly altering the $S$ phase. $\mathrm{i}-1$ represent the significant difference in the G2 phase of cell cycle caused by the effect of PEG concentration, whereas $\mathrm{m}$ and $\mathrm{n}$ represent the significant difference due to the effect of the AuNP core size. $\mathrm{o}, \mathrm{p}$, and $\mathrm{r}$ represent the significant differences caused by the particles with respect to control cases in G1, S, and G2 phases, respectively, $(p<0.05)$.

It shows that the core size and/or PEG hydrodynamic volume are the primary factors for the cell viability rather than the PEG grafting density, surface charge, and particle size after serum incubation. Among the cell lines tested, PC3 was the most significantly influenced by the nanoparticles, whereas the same particles caused different levels of toxicity on the cell types because of different characteristics of the cells or intracellular fate of the particles. ${ }^{55,63}$

Effect of PEG-Modified AuNPs on Cell Cycle, Apoptosis, and DNA Damage. Literature studies have demonstrated that the nanoparticles, which do not show any toxic effect according to the classical toxicity test results, may severely disrupt cell cycle steps and cause DNA damage or apoptosis. ${ }^{54}$ Therefore, besides the classical toxicity tests, it is also important to further investigate the effect of the particles on cell cycle steps. Cell cycle is basically the mechanism responsible for cell division and replication. It consists of four subsequently connected phases (G1, S, G2, and M) where the activation of each phase depends on the proper completion of the previous one. A regular cell cycle starts with the G1 phase in which cells prepare themselves for growth by increasing their sizes. Following the G1 phase, the cells synthesize DNA during the $S$ phase. Finally, during the G2/M phase, cells synthesize proteins required for cell division and cell division occurs resulting in the formation of two daughter cells. ${ }^{77,78}$ In this study, the effect of particles on cell cycle is investigated through flow cytometry measurements. The changes in the G1, S, and G2 phases for all cells treated with the particles are shown in Figures 6-8 (for the histograms of cell cycle see Figures S8S10).

The results indicated that all of the particles caused severe alteration in all cell cycle steps for both cancer cell lines, $\mathrm{CaCo} 2$ and PC3, although their cellular accumulation significantly varied. In the case of the healthy fibroblast cell line, 3T3, particles $A$ and $F\left(0.67-0.62\right.$ chains $\left./ \mathrm{nm}^{2}\right)$ with the same grafting densities did not cause a significant cell cycle arrest even though they displayed different cellular accumulation (Figure 2). On the other hand, particles $\mathrm{C}$ and $\mathrm{D}$ possessing the highest $\left(0.92\right.$ chains $\left./ \mathrm{nm}^{2}\right)$ and the lowest $\left(0.36\right.$ chains $\left./ \mathrm{nm}^{2}\right)$ grafting densities increased the $S$ phase and decreased the G2 phase arrest in $3 \mathrm{~T} 3$ cells. It seems that an optimum PEG grafting density $\left(\sim 0.65\right.$ chains $\left./ \mathrm{nm}^{2}\right)$ existed at which particles 


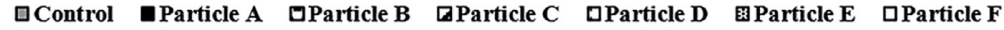

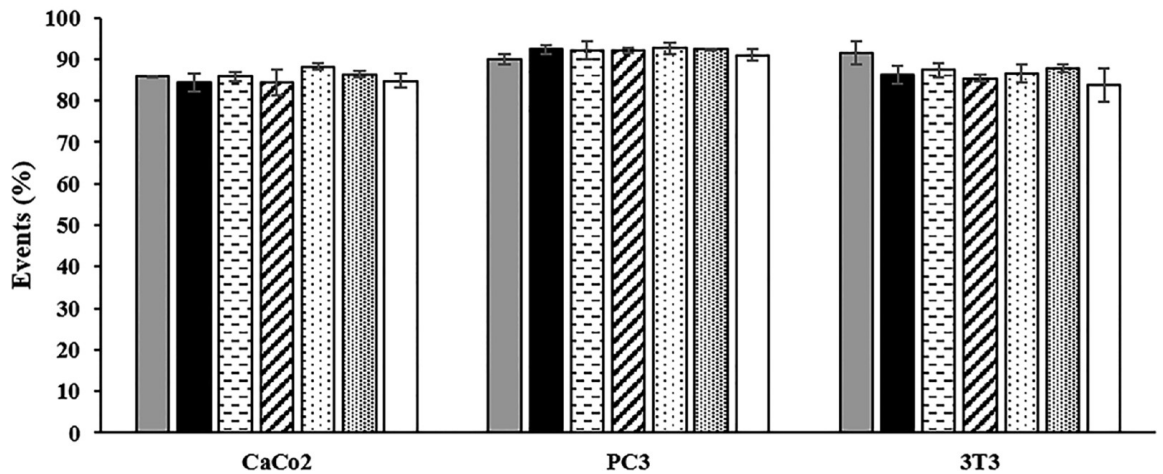

Figure 9. Apoptosis analysis of AuNP-PEG particle-exposed $(50 \mu \mathrm{M}) \mathrm{CaCo} 2, \mathrm{PC} 3$, and $3 \mathrm{~T} 3$ cells using flow cytometry. Incubation time: 24 h.

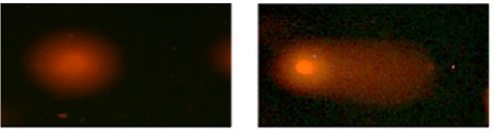

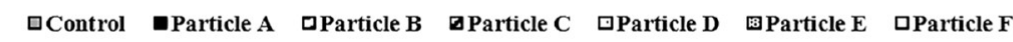

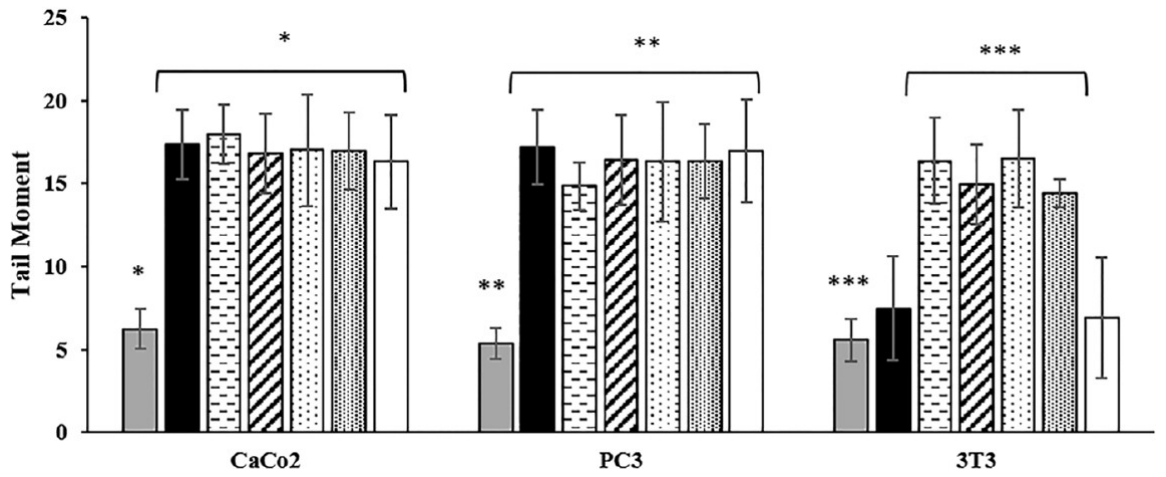

Figure 10. Tail moments of the cells exposed to AuNP-PEG particles $(50 \mu \mathrm{M})$. Incubation time: $24 \mathrm{~h} . *, * *$, and $* * *$ represent the significant difference of AuNP-PEG particles with respect to control groups $(p<0.05)$.

did not severely alter the cell cycle phases for $3 \mathrm{~T} 3$ cells. Thus, it may be possible to minimize the alteration in cell cycle upon exposure to AuNPs by changing the PEG grafting density. No direct correlation was found between the toxicity and cell cycle results. For instance, particles $\mathrm{A}$ and $\mathrm{C}$ showed different cell viabilities (particle A: $\sim 60 \%$ and particle C: $\sim 80 \%$ ) against PC3 cells (Figure 4); however, the disruption of cell cycle phases caused by each particle was not significantly different (Figure 7). Particles C and D did not show severe toxicity ( $\sim 80 \%$ cell viability) on $3 \mathrm{~T} 3$ cells (Figure 5), yet they resulted in a significant $\mathrm{S}$ phase arrest (Figure 8). Similarly, the severe cell cycle phase arrest in nontoxic doses of applied nanoparticles was also reported in the literature. ${ }^{54}$

The cells can be arrested at cell cycle checkpoints temporarily to repair cellular damage, to dissipate an exogenous cellular stress signal, or to provide essential growth factors, hormones, or nutrients. Besides, in case the cellular damage is too severe to be repaired, the activation of pathways leading to apoptosis (programmed cell death) occurs through checkpoint signaling. ${ }^{77}$ Although the particles caused significant cell cycle phase arrests, they did not depict an apoptotic effect against the cells (Figure 9). In addition, it was also observed that none of the cells showed apoptotic behavior upon incubation with particles during 48 and $72 \mathrm{~h}$ (Figure S11). This result implies that the particles regardless of their physicochemical and surface properties acted through pathways other than apoptosis to inhibit cell growth or that they caused retarded cell proliferation without accompanied massive apoptosis. ${ }^{55}$

Previous studies have shown that cells are arrested at different phases of cell cycle or triggered apoptosis mechanisms because of DNA damage caused by external or internal effects. $^{77-79}$ Basically, DNA damage triggers a signaling network that induces phosphorylation and consequent activation of ATM (Ataxia telangiectasia mutated), which functions in DNA repair, apoptotic death, and cell cycle arrest. $^{54,78,79}$ We investigated possible DNA damage caused by the PEG-coated AuNP particles using comet assay, which detects single- and double-strand DNA breaks at individual cells. Cells that have broken DNA fragments or damaged DNA migrate much further and appear as fluorescent comets with tails of DNA fragmentation, whereas undamaged DNA moves minimally because of its large size. ${ }^{54}$ Our comet assay results indicated that all particles caused DNA damage for cancer cells. This suggests that PEGylated AuNPs reach the nucleus where most of the DNA related events take place.

The results in Figure 10 indicated that for $\mathrm{CaCo} 2$ and PC3 cell lines, all particles caused significant DNA damage almost at the same level. In the case of $3 \mathrm{~T} 3$ cells, particles A and F with the same PEG grafting densities $\left(\sim 0.67\right.$ and 0.62 chains $\left./ \mathrm{nm}^{2}\right)$ did not induce any DNA damage, whereas particles C and D (with PEG grafting densities of 0.92 and 0.36 chains $/ \mathrm{nm}^{2}$ ) showed a severe DNA damage. This result is in accordance with 
the cell cycle alterations of 3T3 cells illustrated in Figure 8. From the results, it appeared that an optimum PEG grafting density also existed for the effect of particles on DNA integrity. It is known that the same particles possessing the same chemical and physical properties affected cancer and normal cell lines differently because of differences in their interactions with cells. Kang et al., (2010) have proved that $0.4 \mathrm{nM}$ concentration of AuNPs targeting the nucleus of cancer cells caused disruption of cytokinesis inhibiting these cells from completing cell division, triggering DNA damage, and following apoptosis; however, none of these effects were observed in any normal cell groups treated by the same amount and type of AuNP. ${ }^{52}$ In our study, particles with a grafting density of $\sim 0.65$ did not cause any cell cycle arrest and DNA damage in 3T3 cells, whereas the particles with grafting density below and above this value $(\sim 0.65)$ caused significant cell cycle alteration and DNA damage. This is thought to be because of the different surface properties of the particles. It is expected for the particles to have relatively different hydrophobic surfaces because of their different PEG grafting densities, hydrodynamic volumes, and also conformations, which results in different interactions with cell culture media components and cells. Further investigations are required to analyze these differences, and this should be the focus of future studies.

The reason for DNA damage is generally explained by the accumulation of the particles around the nucleus where the DNA content is high. To support this hypothesis, all three types of cells were imaged after the incubation with particle D using the fluorescence images. This particle was selected because it caused the highest toxicity and the most significant alteration on the cell cycle phases. The images in Figure 11
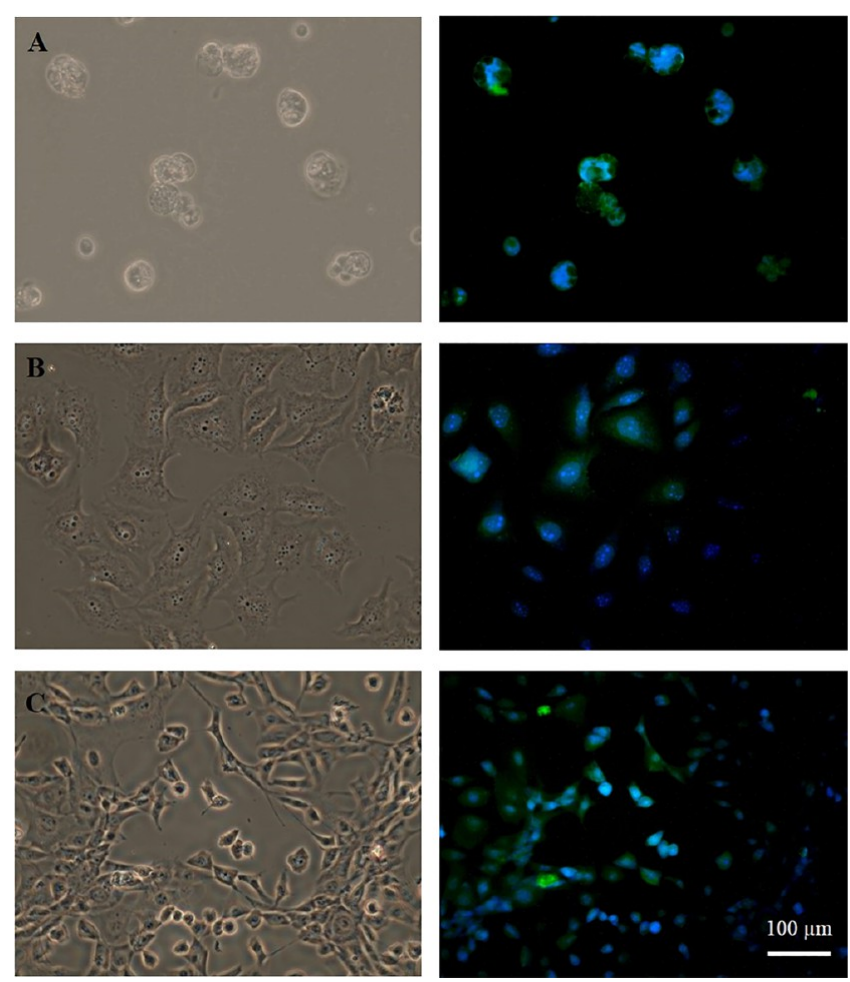

Figure 11. Light and merged fluorescence images of particle D $(13 \mathrm{~nm}$ sized AuNPs with $0.2 \mathrm{mg} / \mathrm{mL}$ PEG coating) in (A) $\mathrm{CaCo} 2$, (B) PC3, and (C) 3T3 cells. Incubation time: $24 \mathrm{~h}$. Blue: nucleus staining with DAPI. Green: particle staining with FITC. showed that the nanoparticles entered the nucleus of all cell types, which support the results obtained from cell cycle and DNA damage experiments. ${ }^{19,52}$ In all three images, the cell morphologies are similar to the morphology of the cells before treatment (Figure S12) indicating no apoptotic behavior because of the exposure to particles.

\section{CONCLUSION}

In this study, different PEG-coated AuNPs, obtained by changing the AuNP core size and PEG coating concentrations, were characterized in terms of cumulative size, surface charge, PEG layer conformation, grafting density, and hydrodynamic volume. In particular, the effects of PEG grafting density and hydrodynamic volume on stability (protein adsorption), cellular uptake, toxicity, cell cycle, apoptosis, and DNA damage were evaluated. The results indicated that the adsorbed PEG molecules achieved brush conformation on all nanoparticles; however, the PEG grafting densities and hydrodynamic volumes on the particles were different depending on the core size and PEG concentration. PEG hydrodynamic volume, steric hindrance, and core size had control over protein adsorption, stability, cellular uptake, and toxicity, whereas PEG grafting density was found to be the major factor determining the effect of particles on cell cycle and DNA damage. All of the particles formulated, regardless of their surface properties, led to significant cell cycle alteration and DNA damage especially against $\mathrm{CaCo} 2$ and $\mathrm{PC} 3$ cancer cells at certain doses without causing any apoptotic behavior. However, in healthy 3T3 cells, the particles possessing certain PEG grafting density values $\left(\sim 0.65\right.$ chains $\left./ \mathrm{nm}^{2}\right)$ did not cause any significant cell cycle alteration, apoptosis, or DNA damage, whereas below or above this value severe damage was observed. Considering the fact that the renal clearance of gold particles is possible if their sizes are smaller than $10 \mathrm{~nm}$, it can be suggested that particles prepared from the $5 \mathrm{~nm}$ AuNP core size with $\sim 0.65$ chains/ $\mathrm{nm}^{2}$ PEG grafting density could be a good candidate for further in vivo investigations. Overall, these results suggested that depending on the cell type, it is possible to adjust PEG grafting density and hydrodynamic volume at a certain value in which particles are not only capable of keeping their stability and providing efficient cellular uptake but also not causing cell cycle arrest, apoptosis, or DNA damage.

\section{ASSOCIATED CONTENT}

Supporting Information

The Supporting Information is available free of charge on the ACS Publications website at DOI: 10.1021/acs.langmuir.6b01289.

Detailed information about the calculation of the number of AuNPs per cell by ICP-MS analysis and the results regarding the XPS, UV-vis spectrophotometry, DLS, TGA, and cell cycle histograms (PDF)

\section{AUTHOR INFORMATION}

\section{Corresponding Author}

*E-mail: sacidealsoy@iyte.edu.tr. Phone: +90 2307506658. Fax: +902327506645.

\section{Notes}

The authors declare no competing financial interest. 


\section{ACKNOWLEDGMENTS}

The authors would like to thank Izmir Institute of Technology for the financial support through Grant 2011IYTE10. We also gratefully acknowledge Izmir Institute of Technology Biotechnology and Bioengineering Research and Application Center and Dr. Surya K. Mallapragada for providing access to TEM analysis.

\section{REFERENCES}

(1) Elbakry, A.; Zaky, A.; Liebl, R; Rachel, R.; Goepferich, A.; Breunig, M. Layer-by-Layer Assembled Gold Nanoparticles for siRNA Delivery. Nano Lett. 2009, 9, 2059-2064.

(2) Ghosh, P. S.; Kim, C.-K.; Han, G.; Forbes, N. S.; Rotello, V. M. Efficient Gene Delivery Vectors by Tuning the Surface Charge Density of Amino Acid-Functionalized Gold Nanoparticles. ACS Nano 2008, 2, 2213-2218.

(3) Guo, S.; Huang, Y.; Jiang, Q.; Sun, Y.; Deng, L.; Liang, Z.; Du, Q.; Xing, J.; Zhao, Y.; Wang, P. C.; Dong, A.; Liang, X.-J. Enhanced Gene Delivery and siRNA Silencing by Gold Nanoparticles Coated with Charge-Reversal Polyelectrolyte. ACS Nano 2010, 4, 5505-5511.

(4) Lee, J.-S.; Green, J. J.; Love, K. T.; Sunshine, J.; Langer, R.; Anderson, D. G. Gold, Poly( $\beta$-amino ester) Nanoparticles for Small Interfering RNA Delivery. Nano Lett. 2009, 9, 2402-2406.

(5) Lee, M.-Y.; Park, S.-J.; Park, K.; Kim, K. S.; Lee, H.; Hahn, S. K. Target-Specific Gene Silencing of Layer-by-Layer Assembled GoldCysteamine/siRNA/PEI/HA Nanocomplex. ACS Nano 2011, 5, 6138-6147.

(6) Lee, Y.; Lee, S. H.; Kim, J. S.; Maruyama, A.; Chen, X.; Park, T. G. Controlled synthesis of PEI-coated gold nanoparticles using reductive catechol chemistry for siRNA delivery. J. Controlled Release 2011, 155, 3-10.

(7) Coelho, S. C.; Rangel, M.; Pereira, M. C.; Coelho, M. A. N.; Ivanova, G. Structural characterization of functionalized gold nanoparticles for drug delivery in cancer therapy: a NMR based approach. Phys. Chem. Chem. Phys. 2015, 17, 18971-18979.

(8) Uz, M.; Mallapragada, S. K.; Altinkaya, S. A. Responsive pentablock copolymers for siRNA delivery. RSC Adv. 2015, 5, 4351543527.

(9) Cai, Q.-Y.; Kim, S. H.; Choi, K. S.; Kim, S. Y.; Byun, S. J.; Kim, K. W.; Park, S. H.; Juhng, S. K.; Yoon, K.-H. Colloidal gold nanoparticles as a blood-pool contrast agent for X-ray computed tomography in mice. Invest. Radiol. 2007, 42, 797-806.

(10) Kim, D.; Park, S.; Lee, J. H.; Jeong, Y. Y.; Jon, S. Antibiofouling polymer-coated gold nanoparticles as a contrast agent for in vivo $\mathrm{X}$-ray computed tomography imaging. J. Am. Chem. Soc. 2007, 129, 76617665 .

(11) Li, J.- L.; Wang, L.; Liu, X.-Y.; Zhang, Z.-P.; Guo, H.-C.; Liu, W.M.; Tang, S.-H. In vitro cancer cell imaging and therapy using transferrin-conjugated gold nanoparticles. Cancer Lett. 2009, 274, 319-326.

(12) Shukla, S.; Priscilla, A.; Banerjee, M.; Bhonde, R. R.; Ghatak, J.; Satyam, P. V.; Sastry, M. Porous gold nanospheres by controlled transmetalation reaction: A novel material for application in cell imaging. Chem. Mater. 2005, 17, 5000-5005.

(13) Wang, L.; Liu, Y.; Li, W.; Jiang, X.; Ji, Y.; Wu, X.; Xu, L.; Qiu, Y.; Zhao, K.; Wei, T.; Li, Y.; Zhao, Y.; Chen, C. Selective Targeting of Gold Nanorods at the Mitochondria of Cancer Cells: Implications for Cancer Therapy. Nano Lett. 2011, 11, 772-780.

(14) Roa, W.; Zhang, X.; Guo, L.; Shaw, A.; Hu, X.; Xiong, Y.; Gulavita, S.; Patel, S.; Sun, X.; Chen, J.; Moore, R.; Xing, J. Z. Gold nanoparticle sensitize radiotherapy of prostate cancer cells by regulation of the cell cycle. Nanotechnology 2009, 20, 375101.

(15) Bogdanov, A. A.; Gupta, S.; Koshkina, N.; Corr, S. J.; Zhang, S.; Curley, S. A.; Han, G. Gold Nanoparticles Stabilized with MPEGGrafted Poly(L-lysine): In Vitro and In Vivo Evaluation of a Potential Theranostic Agent. Bioconjugate Chem. 2015, 26, 39-50.

(16) Bhattacharya, R.; Mukherjee, P. Biological properties of "naked" metal nanoparticles. Adv. Drug Delivery Rev. 2008, 60, 1289-1306.
(17) Ghosh, P.; Han, G.; De, M.; Kim, C. K.; Rotello, V. M. Gold nanoparticles in delivery applications. Adv. Drug Delivery Rev. 2008, 60, 1307-1315.

(18) Pissuwan, D.; Niidome, T.; Cortie, M. B. The forthcoming applications of gold nanoparticles in drug and gene delivery systems. J. Controlled Release 2011, 149, 65-71.

(19) Gu, Y.-J.; Cheng, J.; Lin, C.-C.; Lam, Y. W.; Cheng, S. H.; Wong, W.-T. Nuclear penetration of surface functionalized gold nanoparticles. Toxicol. Appl. Pharmacol. 2009, 237, 196-204.

(20) Simpson, C. A.; Agrawal, A. C.; Balinski, A.; Harkness, K. M.; Cliffel, D. E. Short-Chain PEG Mixed Monolayer Protected Gold Clusters Increase Clearance and Red Blood Cell Counts. ACS Nano 2011, 5, 3577-3584.

(21) Simpson, C. A.; Huffman, B. J.; Gerdon, A. E.; Cliffel, D. E. Unexpected Toxicity of Mono Layer Protected Gold Clusters Eliminated by PEG-Thiol Place Exchange Reactions. Chem. Res. Toxicol. 2010, 23, 1608-1616.

(22) Simpson, C. A.; Salleng, K. J.; Cliffel, D. E.; Feldheim, D. L. In vivo toxicity, biodistribution, and clearance of glutathione-coated gold nanoparticles. Nanomedicine 2013, 9, 257-263.

(23) Walkey, C. D.; Olsen, J. B.; Guo, H.; Emili, A.; Chan, W. C. W. Nanoparticle Size and Surface Chemistry Determine Serum Protein Adsorption and Macrophage Uptake. J. Am. Chem. Soc. 2012, 134, 2139-2147.

(24) Lee, S. H.; Bae, K. H.; Kim, S. H.; Lee, K. R.; Park, T. G. Aminefunctionalized gold nanoparticles as non-cytotoxic and efficient intracellular siRNA delivery carriers. Int. J. Pharm. 2008, 364, 94-101.

(25) Lytton-Jean, A. K. R.; Langer, R.; Anderson, D. G. Five Years of siRNA Delivery: Spotlight on Gold Nanoparticles. Small 2011, 7, 1932-1937.

(26) Oishi, M.; Nakaogami, J.; Ishii, T.; Nagasaki, Y. Smart PEGylated gold nanoparticles for the cytoplasmic delivery of siRNA to induce enhanced gene silencing. Chem. Lett. 2006, 35, 1046-1047.

(27) Shenoy, D.; Fu, W.; Li, J.; Crasto, C.; Jones, G.; DiMarzio, C.; Sridhar, S.; Amiji, M. Surface functionalization of gold nanoparticles using hetero-bifunctional poly(ethylene glycol) spacer for intracellular tracking and delivery. Int. J. Nanomed. 2006, 1, 51-58.

(28) Boyer, C.; Whittaker, M. R.; Luzon, M.; Davis, T. P. Design and Synthesis of Dual Thermoresponsive and Antifouling Hybrid Polymer/Gold Nanoparticles. Macromolecules 2009, 42, 6917-6926.

(29) Chithrani, B. D.; Ghazani, A. A.; Chan, W. C. W. Determining the size and shape dependence of gold nanoparticle uptake into mammalian cells. Nano Lett. 2006, 6, 662-668.

(30) Connor, E. E.; Mwamuka, J.; Gole, A.; Murphy, C. J.; Wyatt, M. D. Gold nanoparticles are taken up by human cells but do not cause acute cytotoxicity. Small 2005, 1, 325-327.

(31) Tsoli, M.; Kuhn, H.; Brandau, W.; Esche, H.; Schmid, G. Cellular uptake and toxicity of $\mathrm{Au}(55)$ clusters. Small 2005, 1, 841844.

(32) Kim, J. A.; Åberg, C.; Salvati, A.; Dawson, K. A. Role of cell cycle on the cellular uptake and dilution of nanoparticles in a cell population. Nat. Nanotechnol. 2011, 7, 62-68.

(33) Vetten, M. A.; Tlotleng, N.; Rascher, D. T.; Skepu, A.; Keter, F. K.; Boodhia, K.; Koekemoer, L.-A.; Andraos, C.; Tshikhudo, R.; Gulumian, M. Label-free in vitro toxicity and uptake assessment of citrate stabilised gold nanoparticles in three cell lines. Part. Fibre Toxicol. 2013, 10, 50.

(34) Freese, C.; Gibson, M. I.; Klok, H.-A.; Unger, R. E.; Kirkpatrick, C. J. Size- and Coating-Dependent Uptake of Polymer-Coated Gold Nanoparticles in Primary Human Dermal Microvascular Endothelial Cells. Biomacromolecules 2012, 13, 1533-1543.

(35) Fytianos, K.; Rodriguez-Lorenzo, L.; Clift, M. J. D.; Blank, F.; Vanhecke, D.; von Garnier, C.; Petri-Fink, A.; Rothen-Rutishauser, B. Uptake efficiency of surface modified gold nanoparticles does not correlate with functional changes and cytokine secretion in human dendritic cells in vitro. Nanomedicine 2015, 11, 633-644.

(36) Liu, H.; Doane, T. L.; Cheng, Y.; Lu, F.; Srinivasan, S.; Zhu, J.-J.; Burda, C. Control of Surface Ligand Density on PEGylated Gold 
Nanoparticles for Optimized Cancer Cell Uptake. Part. Part. Syst. Charact. 2014, 32, 197-204.

(37) Soenen, S. J.; Manshian, B. B.; Abdelmonem, A. M.; Montenegro, J.-M.; Tan, S.; Balcaen, L.; Vanhaecke, F.; Brisson, A. R.; Parak, W. J.; De Smedt, S. C.; Braeckmans, K. The Cellular Interactions of PEGylated Gold Nanoparticles: Effect of PEGylation on Cellular Uptake and Cytotoxicity. Part. Part. Syst. Charact. 2014, 31, 794-800.

(38) Shukla, R.; Bansal, V.; Chaudhary, M.; Basu, A.; Bhonde, R. R.; Sastry, M. Biocompatibility of gold nanoparticles and their endocytotic fate inside the cellular compartment: A microscopic overview. Langmuir 2005, 21, 10644-10654.

(39) Cho, W.-S.; Cho, M.; Jeong, J.; Choi, M.; Han, B. S.; Shin, H.-S.; Hong, J.; Chung, B. H.; Jeong, J.; Cho, M.-H. Size-dependent tissue kinetics of PEG-coated gold nanoparticles. Toxicol. Appl. Pharmacol. 2010, 245, 116-123.

(40) Tatini, F.; Landini, I.; Scaletti, F.; Massai, L.; Centi, S.; Ratto, F.; Nobili, S.; Romano, G.; Fusi, F.; Messori, L.; Mini, E.; Pini, R. Size dependent biological profiles of PEGylated gold nanorods. J. Mater. Chem. B 2014, 2, 6072-6080.

(41) Wang, J.; Bai, R.; Yang, R.; Liu, J.; Tang, J.; Liu, Y.; Li, J.; Chai, Z.; Chen, C. Size- and surface chemistry-dependent pharmacokinetics and tumor accumulation of engineered gold nanoparticles after intravenous administration. Metallomics 2015, 7, 516-524.

(42) You, J.; Zhou, J.; Zhou, M.; Liu, Y.; Robertson, J.; Liang, D.; Van Pelt, C.; Li, C. Pharmacokinetics, clearance, and biosafety of polyethylene glycol-coated hollow gold nanospheres. Part. Fibre Toxicol. 2014, 11, 26.

(43) Pan, Y.; Neuss, S.; Leifert, A.; Fischler, M.; Wen, F.; Simon, U.; Schmid, G.; Brandau, W.; Jahnen-Dechent, W. Size-dependent cytotoxicity of gold nanoparticles. Small 2007, 3, 1941-1949.

(44) Zhang, X.-D.; Wu, D.; Shen, X.; Liu, P. X.; Yang, N.; Zhao, B.; Zhang, H.; Sun, Y. M.; Zhang, L. A.; Fan, F. Y. Size-dependent in vivo toxicity of PEG-coated gold nanoparticles. Int. J. Nanomed. 2011, 6, 2071-2081.

(45) Gong, T.; Goh, D.; Olivo, M.; Yong, K.-T. In vitro toxicity and bioimaging studies of gold nanorods formulations coated with biofunctional thiol-PEG molecules and Pluronic block copolymers. Beilstein J. Nanotechnol. 2014, 5, 546-553.

(46) Leite, P. E. C.; Pereira, M. R.; Santos, C. A. D.; Campos, A. P. C.; Esteves, T. M.; Granjeiro, J. M. Gold nanoparticles do not induce myotube cytotoxicity but increase the susceptibility to cell death. Toxicol. In Vitro 2015, 29, 819-827.

(47) Patlolla, A. K.; Epting, T.; Thrasher, L.; Tchounwou, P. B. Cytotoxic and genotoxic effects of PEG-coated gold nanoparticles in HK-2 cells. Cancer Res. 2014, 74, 2284.

(48) Adnan, N. N. M.; Cheng, Y. Y.; Ong, N. M. N.; Kamaruddin, T. T.; Rozlan, E.; Schmidt, T. W.; Duong, H. T. T.; Boyer, C. Effect of gold nanoparticle shapes for phototherapy and drug delivery. Polym. Chem. 2016, 7, 2888-2903.

(49) Austin, L. A.; Kang, B.; Yen, C.-W.; El-Sayed, M. A. Nuclear Targeted Silver Nanospheres Perturb the Cancer Cell Cycle Differently than Those of Nanogold. Bioconjugate Chem. 2011, 22, 2324-2331.

(50) Butterworth, K. T.; Coulter, J. A.; Jain, S.; Forker, J.; McMahon, S. J.; Schettino, G.; Prise, K. M.; Currell, F. J.; Hirst, D. G. Evaluation of cytotoxicity and radiation enhancement using $1.9 \mathrm{~nm}$ gold particles: potential application for cancer therapy. Nanotechnology 2010, 21, 295101.

(51) Choi, S. Y.; Jeong, S.; Jang, S. H.; Park, J.; Park, J. H.; Ock, K. S.; Lee, S. Y.; Joo, S.-W. In vitro toxicity of serum protein-adsorbed citrate-reduced gold nanoparticles in human lung adenocarcinoma cells. Toxicol. In Vitro 2012, 26, 229-237.

(52) Kang, B.; Mackey, M. A.; El-Sayed, M. A. Nuclear Targeting of Gold Nanoparticles in Cancer Cells Induces DNA Damage, Causing Cytokinesis Arrest and Apoptosis. J. Am. Chem. Soc. 2010, 132, 15171519.

(53) Li, J. J.; Lo, S.-L.; Ng, C.-T.; Gurung, R. L.; Hartono, D.; Hande, M. P.; Ong, C.-N.; Bay, B.-H.; Yung, L.-Y. L. Genomic instability of gold nanoparticle treated human lung fibroblast cells. Biomaterials 2011, 32, 5515-5523.

(54) Wan, R.; Mo, Y.; Feng, L.; Chien, S.; Tollerud, D. J.; Zhang, Q. DNA damage caused by metal nanoparticles: involvement of oxidative stress and activation of ATM. Chem. Res. Toxicol. 2012, 25, 14021411.

(55) Chuang, S.-M.; Lee, Y.-H.; Liang, R.-Y.; Roam, G.-D.; Zeng, Z.M.; Tu, H.-F.; Wang, S.-K.; Chueh, P. J. Extensive evaluations of the cytotoxic effects of gold nanoparticles. Biochim. Biophys. Acta, Gen. Subj. 2013, 1830, 4960-4973.

(56) Molineux, G. Pegylation: Engineering improved biopharmaceuticals for oncology. Pharmacotherapy 2003, 23, 3S-8S.

(57) Manjula, B. N.; Tsai, A.; Upadhya, R.; Perumalsamy, K.; Smith, P. K.; Malavalli, A.; Vandegriff, K.; Winslow, R. M.; Intaglietta, M.; Prabhakaran, M.; Friedman, J. M.; Acharya, A. S. Site-specific PEGylation of hemoglobin at cys-93(beta): Correlation between the colligative properties of the PEGylated protein and the length of the conjugated PEG chain. Bioconjugate Chem. 2003, 14, 464-472.

(58) Jeong, J. H.; Kim, S. W.; Park, T. G. Novel intracellular delivery system of antisense oligonucleotide by self-assembled hybrid micelles composed of DNA/PEG conjugate and cationic fusogenic peptide. Bioconjugate Chem. 2003, 14, 473-479.

(59) Alric, C.; Miladi, I.; Kryza, D.; Taleb, J.; Lux, F.; Bazzi, R.; Billotey, C.; Janier, M.; Perriat, P.; Roux, S.; Tillement, O. The biodistribution of gold nanoparticles designed for renal clearance. Nanoscale 2013, 5, 5930-5939.

(60) Balasubramanian, S. K.; Jittiwat, J.; Manikandan, J.; Ong, C.-N.; Yu, L. E.; Ong, W.-Y. Biodistribution of gold nanoparticles and gene expression changes in the liver and spleen after intravenous administration in rats. Biomaterials 2010, 31, 2034-2042.

(61) Liu, J.; Yu, M.; Zhou, C.; Zheng, J. Renal clearable inorganic nanoparticles: a new frontier of bionanotechnology. Mater. Today 2013, 16, 477-486.

(62) Zhang, X.-D.; Luo, Z.; Chen, J.; Wang, H.; Song, S.-S.; Shen, X.; Long, W.; Sun, Y.-M.; Fan, S.; Zheng, K.; Leong, D. T.; Xie, J. Storage of Gold Nanoclusters in Muscle Leads to their Biphasic in Vivo Clearance. Small 2015, 11, 1683-1690.

(63) Patra, H. K.; Banerjee, S.; Chaudhuri, U.; Lahiri, P.; Dasgupta, A. K. Cell selective response to gold nanoparticles. Nanomedicine 2007, $3,111-119$

(64) Lin, I.-C.; Liang, M.; Liu, T.-Y.; Monteiro, M. J.; Toth, I. Cellular transport pathways of polymer coated gold nanoparticles. Nanomedicine 2012, 8, 8-11.

(65) Arnida; Malugin, A.; Ghandehari, H. Cellular uptake and toxicity of gold nanoparticles in prostate cancer cells: a comparative study of rods and spheres. J. Appl. Toxicol. 2009, 30, 212-217.

(66) Coradeghini, R.; Gioria, S.; Garcia, C. P.; Nativo, P.; Franchini, F.; Gilliland, D.; Ponti, J.; Rossi, F. Size-dependent toxicity and cell interaction mechanisms of gold nanoparticles on mouse fibroblasts. Toxicol. Lett. 2013, 217, 205-216.

(67) Turkevich, J.; Stevenson, P. C.; Hillier, J. A study of the nucleation and growth processes in the synthesis of colloidal gold. Discuss. Faraday Soc. 1951, 11, 55-75.

(68) Yang, J.; Lee, J. Y.; Too, H.-P.; Chow, G.-M.; Gan, L. M. Single stranded DNA stabilization and assembly of $\mathrm{Au}$ nanoparticles of different sizes. Chem. Phys. 2006, 323, 304-312.

(69) Rahme, K.; Chen, L.; Hobbs, R. G.; Morris, M. A.; O’Driscoll, C.; Holmes, J. D. PEGylated gold nanoparticles: polymer quantification as a function of PEG lengths and nanoparticle dimensions. RSC Adv. 2013, 3, 6085-6094.

(70) Takae, S.; Akiyama, Y.; Otsuka, H.; Nakamura, T.; Nagasaki, Y.; Kataoka, K. Ligand density effect on biorecognition by PEGylated gold nanoparticles: regulated interaction of RCA120 lectin with lactose installed to the distal end of tethered PEG strands on gold surface. Biomacromolecules 2005, 6, 818-824.

(71) Olive, P. L.; Banáth, J. P. The comet assay: a method to measure DNA damage in individual cells. Nat. Protoc. 2006, 1, 23-29.

(72) Damodaran, V. B.; Fee, C. J.; Ruckh, T.; Popat, K. C. Conformational Studies of Covalently Grafted Poly(ethylene glycol) 
on Modified Solid Matrices Using X-ray Photoelectron Spectroscopy. Langmuir 2010, 26, 7299-7306.

(73) Hu, Y.; Xie, J.; Tong, Y. W.; Wang, C.-H. Effect of PEG conformation and particle size on the cellular uptake efficiency of nanoparticles with the HepG2 cells. J. Controlled Release 2007, 118, 717.

(74) Korpan, M. I.; Gorchev, V. F.; Chekman, I. S.; Gun'ko, V. M.; Fialko-Moser, V. Influence of direct electric current on hydrodynamic diameter of human serum albumin. Ukrains'kyi biokhimichnyi zhurnal 2008, 80, 114-118.

(75) Armstrong, J. K.; Wenby, R. B.; Meiselman, H. J.; Fisher, T. C. The Hydrodynamic Radii of Macromolecules and Their Effect on Red Blood Cell Aggregation. Biophys. J. 2004, 87, 4259-4270.

(76) Nicholson, J. P.; Wolmarans, M. R.; Park, G. R. The role of albumin in critical illness. Br. J. Anaesth. 2000, 85, 599-610.

(77) Pietenpol, J. A.; Stewart, Z. A. Cell cycle checkpoint signaling: Cell cycle arrest versus apoptosis. Toxicology 2002, 181, 475-481.

(78) Kastan, M. B.; Bartek, J. Cell-cycle checkpoints and cancer. Nature 2004, 432, 316-323.

(79) Malumbres, M.; Barbacid, M. Cell cycle, CDKs and cancer: a changing paradigm. Nat. Rev. Cancer 2009, 9, 153-166. 